\title{
SOEP
}

SOEPpapers

on Multidisciplinary Panel Data Research

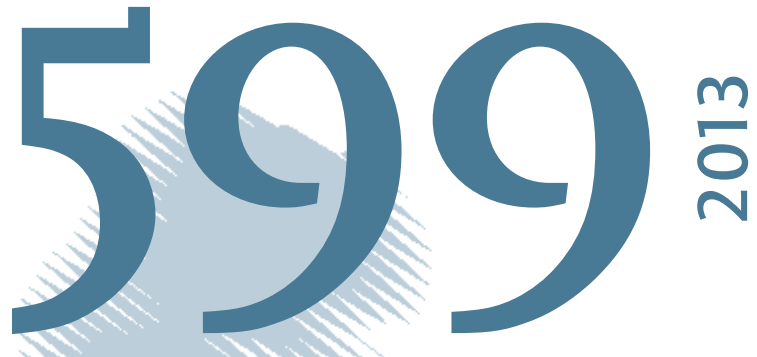

$\frac{m}{n}$

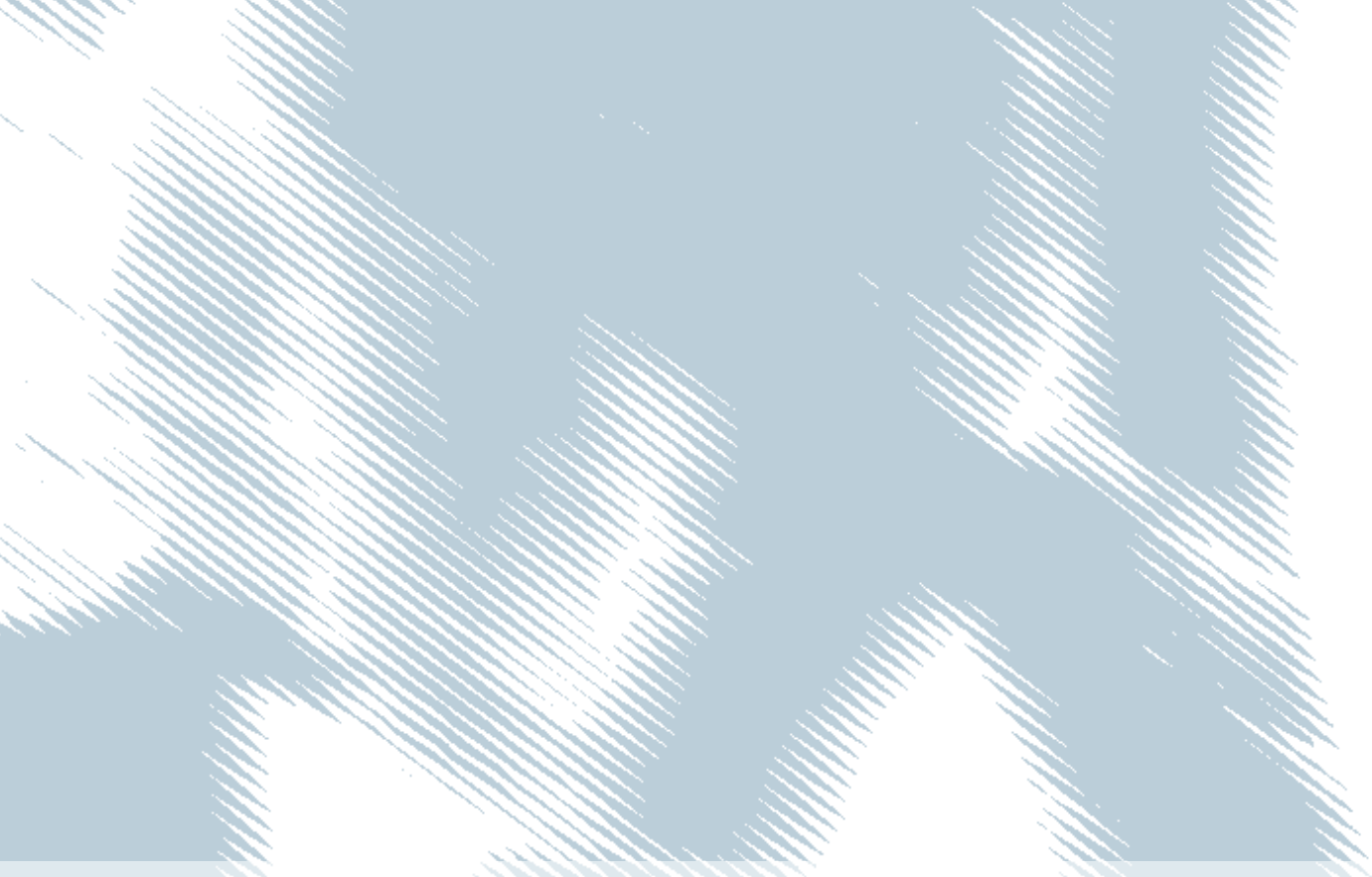

\section{Natural Disaster, Policy Action, and Mental Well-Being: The Case of Fukushima}




\section{SOEPpapers on Multidisciplinary Panel Data Research}

at DIW Berlin

This series presents research findings based either directly on data from the German SocioEconomic Panel Study (SOEP) or using SOEP data as part of an internationally comparable data set (e.g. CNEF, ECHP, LIS, LWS, CHER/PACO). SOEP is a truly multidisciplinary household panel study covering a wide range of social and behavioral sciences: economics, sociology, psychology, survey methodology, econometrics and applied statistics, educational science, political science, public health, behavioral genetics, demography, geography, and sport science.

The decision to publish a submission in SOEPpapers is made by a board of editors chosen by the DIW Berlin to represent the wide range of disciplines covered by SOEP. There is no external referee process and papers are either accepted or rejected without revision. Papers appear in this series as works in progress and may also appear elsewhere. They often represent preliminary studies and are circulated to encourage discussion. Citation of such a paper should account for its provisional character. A revised version may be requested from the author directly.

Any opinions expressed in this series are those of the author(s) and not those of DIW Berlin. Research disseminated by DIW Berlin may include views on public policy issues, but the institute itself takes no institutional policy positions.

The SOEPpapers are available at

http://www.diw.de/soeppapers

\section{Editors:}

Jürgen Schupp (Sociology)

Gert G. Wagner (Social Sciences, Vice Dean DIW Graduate Center)

Conchita D'Ambrosio (Public Economics)

Denis Gerstorf (Psychology, DIW Research Director)

Elke Holst (Gender Studies, DIW Research Director)

Frauke Kreuter (Survey Methodology, DIW Research Professor)

Martin Kroh (Political Science and Survey Methodology)

Frieder R. Lang (Psychology, DIW Research Professor)

Henning Lohmann (Sociology, DIW Research Professor)

Jörg-Peter Schräpler (Survey Methodology, DIW Research Professor)

Thomas Siedler (Empirical Economics)

C. Katharina Spieß (Empirical Economics and Educational Science)

ISSN: 1864-6689 (online)

German Socio-Economic Panel Study (SOEP)

DIW Berlin

Mohrenstrasse 58

10117 Berlin, Germany

Contact: Uta Rahmann | soeppapers@diw.de 


\title{
Natural Disaster, Policy Action, and Mental Well-Being: The Case of Fukushima
}

\author{
Jan Goebel** Christian Krekel*** Tim Tiefenbach**** Nicolas R. Ziebarth*****
}

July 2013

\begin{abstract}
We study the impact of the Fukushima disaster on people's mental well-being in another industrialized country, more than $\mathbf{5 0 0 0}$ miles distant. The meltdown significantly increased environmental concerns by $20 \%$ among the German population. Subsequent drastic policy action permanently shut down the oldest nuclear reactors, implemented the phase-out of the remaining ones, and proclaimed the transition to renewables. This energy policy turnaround is largely supported by the population and equalized the increase in mental distress. We estimate that during the 3 months after the meltdown, Fukushima triggered external monetized health costs worth $€ 250$ per distressed citizen-particularly among risk averse women.
\end{abstract}

Keywords: Fukushima, meltdown, nuclear phase-out, mental health, environmental worries, SOEP

JEL codes: I18, I31, Z13, Q54

*We thank Silke Anger, Peter Eibich, Ronny Freier, Jan Marcus, Jürgen Schupp, Gert G. Wagner, Michael Weinhardt and participants at the Cluster Seminar at DIW Berlin. A special thank goes to Adam Lederer for co-editing this paper. We take responsibility for all remaining errors in and shortcomings of the article.

**DIW Berlin (German Institute for Economic Research), Mohrenstrasse 58, 10117 Berlin, Germany, e-mail: jgoebel@diw.de,

***DIW Berlin (German Institute for Economic Research), Graduate Center of Economic and Social Research, Mohrenstrasse 58, 10117 Berlin, Germany, e-mail: ckrekel@diw.de

*****German Institute for Japanese Studies Tokyo (DIJ), Jochi Kioizaka BIdg, 2F, 7-1 Kioicho, Chiyoda-ku, Tokyo 102-0094, Japan, e-mail: tiefenbach@dijtokyo.org

*****Corresponding author: Cornell University, Policy Analysis and Management (PAM), 106 Martha van Rensselaer Hall, Ithaca, NY 14853, DIW Berlin, and IZA Bonn, e-mail: nrz2@cornell.edu, Phone: +1-(607) 255-1180, Fax: +1-(607) 255-4071. 


\section{Introduction}

Seemingly the worst-case scenario, on March 11, 2011, a natural disaster triggered one of the worst nuclear catastrophes in human history: the Fukushima Daiichi Nuclear Disaster. At about 3pm JST, the Tohoku earthquake, magnitude 9.0, struck off the cost of Japan at an underwater depth of about 30km (19mi). Never before had such a powerful earthquake hit Japan. It triggered a gigantic tsunami with waves up to $40 \mathrm{~m}(133 \mathrm{ft})$. The tsunami's dimensions by far exceeded the safety measures of the Fukushima nuclear power plant whose $5.7 \mathrm{~m}$ (19ft) seawalls where easily topped by the up to $15 \mathrm{~m}$ (49ft) high waves hitting the plant. Although the safety measures met regulatory requirements, in total three of the six reactors fully melted down, leading to the release of radioactive material.

In the subsequent days, the dimension of the catastrophe became apparent. Within two days, up to 200,000 people were evacuated, an estimated 4.5 million were without electricity, and 1.5 million without water. In September 2011, the Japanese Policy Agency concluded that the entire disaster, inclusive of earthquake, tsunami, and nuclear meltdown, resulted in 16,000 deaths, thousands of injured or missing people, and 400,000 collapsed or partially collapsed buildings (INPO, 2011). However, to date, no short-term physical health damages from radioactive radiation have been observed (WHO, 2013).

As a first main contribution, this paper estimates the impact of the Fukushima catastrophe on people's mental well-being in another industrialized country more than 5000 miles away. We find that concerns about environmental protection significantly increased among the German population in the weeks after the meltdown. This finding demonstrates that disasters not only have local impacts, but can also have negative external effects in other countries, even if the country is presumably unaffected and far away. Metcalfe et al. (2011) show that this was true for people living in the UK after the 9/11 terrorist attacks. This paper shows that these global negative external effects may even exist when a disaster in country A objectively does not increase the risk of a similar disaster in country $B$, which is the case for nuclear meltdowns triggered by tsunamis. 
Germany is a particularly interesting country to study in this context since the meltdown led the conservative government, under the leadership of Chancellor Angela Merkel, to make a sharp U-turn in their energy policy. Fukushima "made [Angela Merkel] change her mind about the risks of nuclear energy" (Bundesregierung, 2011a). In consensus with the liberal opposition, the oldest German reactors were temporarily shut down-despite their reputation of being among the safest reactors worldwide and despite the marginal tsunami risk in Germany. On June 30, 2011, the German parliament ("Bundestag") passed a law that permanently shut down these 7 reactors. In addition, it implemented the staggered nuclear phase-out of the remaining reactors. This law will lead to a complete shut-down of all German reactors by 2022 . The German Nuclear Phase Out ("Atomausstieg") is globally unique. It represents a direct and immediate response to the unexpected and exogenous Fukushima catastrophe.

Thus, as a second main contribution, this paper shows how policymakers can alleviate, even reverse, mental concerns in the population through immediate policy action. A representative survey conducted on March 14 2011, revealed that 70\% of all German citizens believed that a nuclear catastrophe similar to Fukushima could also happen in Germany. Accordingly, 71\% were in favor of a complete nuclear phase-out, up from 62\% in August 2010 (Infratest, 2010, 2011a). In line with these survey data, after the passing of the Nuclear Phase-Out Bill, we find that worries about environmental protection significantly decreased-by approximately the same share that they had increased after Fukushima. Again, representative survey data from June 2011 underlines these findings and shows that 54\% of all Germans agree with the specific phase-out bill and also the quick political decision process (Infratest, 2011c). Subsequent to the implementation of the Atomausstieg, we do not find any significant long-term effects of Fukushima on well-being measures.

This paper contributes to the overall literature on mental well-being (Frank, 1981; Oswald, 1997; Winkelmann and Winkelmann, 1998; Frijters et al. 2004; Frank and Koss, 2005; Frey et al. 2007; Senik, 2009; Kassenboehmer and Haisken-DeNew, 2009; Lu et al., 2009; Glied and Frank, 2009; Clark et al., 2008, 2009, 2010; Ojeda et al., 2010; Luechinger et al., 2010; Knabe et al., 2010; Clark and Senik, 2010; Clark and Etilé, 2011; Cahit et al., 2011; Oswald and Wu, 2011; 
Deaton, 2012; Marcus, 2013). More specifically, it contributes to the literature that studies the (mental health) effects of terrorism and natural disasters (Luechinger and Raschky, 2009; Berger, 2010; Draca et al. 2011; Danzer and Danzer, 2011; Metcalfe et al., 2011; Schüller, 2012). Since Fukushima, several papers have discussed the causes and consequences of the catastrophe - however, the large majority focus on Japan (Glaser, 2011; Hippel, 2011; Hommerich, 2012; Huenteler et al. 2012; Ishino et al. 2012; Kawashima and Takeda, 2012; Thomas, 2012; Uchida et al., 2011; Vivoda, 2012; Yamamura, 2012; Aoki and Rothwell, 2013; Csereklyei, 2013; Buesseler et al. 2013; Rieu, 2013; Rehdanz et al. 2013; Tiefenbach and Kohlbacher, 2013; Wang et al., 2013).

The next section briefly describes the events around The Fukushima Disaster and the political reactions in Germany. Section 3 describes the data, whilst Section 4 presents and discusses our findings. Section 5 concludes.

\section{Background}

\subsection{The Fukushima Daiichi Nuclear Disaster}

On March 11, 2011, at 2:46pm local time, a giant earthquake shook the ocean bed about 72 kilometres off the Japanese east coast. Measuring 9.0 on the Richter scale, this earthquake was the largest in Japan since the beginning of record keeping, even shaking skyscrapers in $370 \mathrm{~km}$ (230mi) distant Tokyo. It triggered a giant tsunami with waves reaching up to $40 \mathrm{~m}(133 \mathrm{ft})$. The waves hit the Japanese coast line just 30 minutes thereafter, wiping out cities, villages, and property up to $10 \mathrm{~km}(6.4 \mathrm{mi})$ inland. The receding waters left behind massive destruction, killing 16,000 people (Stern, 2011; Zeit, 2011; INPO, 2011).

The Fukushima Daiichi nuclear power plant is located just $163 \mathrm{~km}(101.5 \mathrm{mi})$ southwest of the epicentre of the earthquake. Shortly after the earthquake, the plant lost its electricity supply and switched to emergency power supply through its diesel generators in order to enable the emergency cooling of the three, out of six, reactors that were in operation at that time, all of which were immediately scrammed. However, even after being scrammed, reactors 
require constant cooling, sometimes for days, in order to keep down their decay heat. When the tsunami flood waves hit the plant, with barriers for flood waves up to $5.7 \mathrm{~m}(19 \mathrm{ft})$, the diesel generators were destroyed and the emergency cooling failed. The consequences were severe. Without constant cooling, the fuel rods of the three reactors that were in operation overheated and slowly began to melt. The vaporising water created immense pressure within the reactor vessels, essentially turning them into giant steam cookers. To counteract, the operator was given the permission to release radioactive steam from the reactors into the surrounding and to feed sea water through the reactor cores (Spiegel, 2011). The traces of radioactive iodine were later found in food and drinking water, even in distant Tokyo, which resulted in a ban on food from certain regions that were considered to be contaminated. Ultimately, however, the countermeasures proved to be ineffective. Hydrogen explosions destroyed the containments of the three reactors that were in operation, damaging the reactor vessels and leaking radioactive particles into the environment (IAEA, 2011a). Everybody within a radius of $10 \mathrm{~km}(6.4 \mathrm{mi})$ around the plant was evacuated immediately on March 11, 2011; it was later extended, creating a $20 \mathrm{~km}(12.8 \mathrm{mi})$ radius permanent exclusion zone.

The Fukushima meltdown was the second largest accident in the history of the peaceful use of nuclear power to date. It was classified 7 on the International Nuclear and Radiological Event Scale (INES) of the International Atomic Energy Agency (IAEA), meaning that there was a major release of radioactive material with widespread health and environmental effects that requires implementation of planned and extended countermeasures (IAEA, 2011b). The scope of the disaster was exceeded only by the 1986 Chernobyl meltdown, which released even more radioactive material into the environment.

\subsection{The Political Reactions in Germany: "Atomausstieg" and "Energiewende"}

Shortly after the Fukushima meltdown, on March 14, 2011, a safety assessment of all 17 remaining operational nuclear power plants in Germany was announced by the government, including a temporary shutdown of the 7 oldest plants. ${ }^{1}$ This policy reaction has become known

\footnotetext{
${ }^{1}$ At that time, the "Krümmel" nuclear power plant was already off grid due to technical problems.
} 
as the "Atom-Moratorium" (Bundesregierung, 2011b). The safety assessment was conducted by the Reactor Safety Commission ("Reaktorsicherheitskommission"). At the same time, an ethics commission ("Ethikkommission für eine sichere Energieversorgung") was appointed to discuss the future of nuclear power in Germany in a broader societal context.

The safety assessment concluded that the 17 remaining operational nuclear power plants in Germany were at least as safe as Fukushima Daiichi and that it was virtually impossible for the accident scenario to occur in Germany. However, it also suggested certain improvements, in particular for older plants, be made. The ethics commission, on the contrary, unequivocally recommended exciting nuclear power within a decade (Reaktorsicherheitskommission, 2011; Ethikkommission für eine sichere Energieversorgung, 2011).

Following the recommendation of the ethics commissions and taking into account the final report of the Reactor Safety Commission, on May 30, 2011, the government announced that it would introduce a Nuclear Phase Out Bill ("13. Gesetz zur Änderung des Atomgesetzes"), which provides for the permanent shutdown of the oldest 7 nuclear power plants in Germany and a reversal of the lifetime extension for the remainder (Bundesregierung, 2011c).

The reversal of the lifetime extension takes back a lifetime extension of 7 years for older and 14 years for newer nuclear power plants in Germany. This extension was initially granted on September 5, 2010, just shortly after the federal elections, which were won by the current conservative government, consisting of a coalition between Christian-Democrats (CDU) and Free Market Liberals (FDP).

The new bill imposes a fixed date for a nuclear phase-out for the first time in history. This policy reaction has become known as the German Nuclear Phase Out ("Atomausstieg"). Still, the decision to amend the law was largely perceived as a campaign move, influenced by the upcoming elections in several German federal states.

The new bill passed the Bundestag on June 30, 2011, and the Federal Council of Germany shortly thereafter, on July 8,2011 . It became effective, alongside a number of other bills that 
promote a change in energy sources from fossils to renewables ("Energiewende"), on August 6, 2011 (Bundesregierung, 2011d; Bundesregierung, 2011e).

\section{Data}

\subsection{Dataset}

We make use of individual-level data provided by the German Socio-Economic Panel Study (SOEP V28). The SOEP is a representative panel study of private households. Interviews have been carried out annually since 1984. All respondents aged 17 and older answer one main individual questionnaire, covering about 150 questions on different topics such as the labor market and family situation, worries, attitudes and perceptions as well as health. Additionally, a household questionnaire is completed by the head of the household. About 20,000 individuals from more than 10,000 households are surveyed each year. For further details, see Wagner, Frick and Schupp (2007).

For our main analyses and our preferred specifications, we exploit the panel dimension of the SOEP and focus on respondents who were interviewed in both 2010 and 2011. In total, we obtain 26,547 person-year observations from 16,460 different individuals of which 10,087 were interviewed in both years and have no missings on their observables. In 2011, roughly half of those 10,087 individuals were interviewed before and after the Fukushima catastrophe, respectively.

For extended analyses and to measure long-term effects, we use SOEP waves Z (2009) to BC (2012) and 58,039 person-year observations.

\subsection{Dependent Variables on Aspects of Mental Well-Being}

We exploit several well-being measures that are routinely surveyed by the SOEP. Our first and main dependent variable is based on the question: "What is your attitude toward environmental protection? Are you concerned about it? (a) very concerned, (b) somewhat concerned, (c) not concerned at all." 
We collapsed the answers to this questions into a binary measure, EnvWorriesLarge, indicating the share of people who are "very concerned" about environmental protection. As seen in the Appendix, on average, $28.6 \%$ of all respondents are "very concerned" about environmental protection.

Analogously, we generate binary variables measuring the share of respondents who are "very concerned" about climate change. Roughly 30\% of all Germans are (see Appendix A).

In addition to these distress measures, we exploit the standard 11 categorical life satisfaction measure. This measure has its mass point between values 5 and 9; 86\% of all respondents fall into these categories.

The SOEP also measures affective well-being and asks respondents to rate how often they felt happy or sad during the 4 weeks prior to the interview. Five answer categories range from "very seldom" to "very often." We collapse the two highest categories "often" and "very often" and generate 3 dichotomous variables accordingly. Appendix A shows that, interestingly, (only) a fifth of all Germans is "often" or "very often" happy while $45 \%$ are "often" or "very often" sad.

Finally, we exploit the continuous physical and the mental health summary scales of the SF12, a quasi-objective health measure included in the 2010 and 2012 SOEP waves (Andersen et al., 2007; Frick and Ziebarth, 2013).

The descriptive statistics for all dependent variables are in the Appendix. Note that these well-being measures represent contemporaneous measures-except for the general well-being measure, which asks about life satisfaction in general.

\subsection{Covariates}

The demographic factors that we use are age, age squared, a female gender dummy, a dummy for being married, single, and disabled, respectively. In addition, we include a dummy indicating those without German nationality. The Appendix shows that the average age is about 
51 years and that slightly more than $50 \%$ are female. Two thirds of all respondents are married and $5 \%$ are not German.

In terms of education and labor market characteristics, we control for the school degree as well as whether respondents are full-time employed (38\%), part-time employed (12\%), out of the labor force (43\%), on maternity leave $(2 \%)$ or unemployed $(5 \%)$.

For extended heterogeneity analyses, as shown in Panel C of the Appendix, we make use of people's political opinions and self-rated risk aversion. The dummy RedGreen indicates that respondents strongly lean toward either the Green party or the Social Democrats, both of which were in the opposition at the time of the disaster. Both parties were strongly in favor of a complete nuclear phase-out. $20 \%$ of all respondents self-identify as strong supporter of one of those parties.

RiskAverse indicates risk aversion and is the collapsed version of the 11 categorical risk aversion measures (Dohmen et al. 2010), whereby we define categories 4 to 1 as risk averse. According to this definition, $50 \%$ of all Germans are risk averse.

\section{[Insert Figure 1 about here]}

Finally, by using geo coordinates at the street block level, we exploit the distance from respondents' place of residences to the nearest nuclear power plant to exploit additional variation and additionally stratify on this variable. Figure 1 shows different radii around the German power plants. We generate a dummy variable that indicates whether respondents live within $50 \mathrm{~km}(31 \mathrm{mi})$ distance to a nuclear power plant (second circle in Figure 1). Almost $30 \%$ of all Germans live within $50 \mathrm{~km}(31 \mathrm{mi})$ a nuclear power plant. ${ }^{2}$ Moreover, in robustness checks to take potential regional sorting into account, we also exploit the distance of the respondents' place of birth to the next nuclear power plant.

\footnotetext{
${ }^{2}$ Traditionally, (intergenerational) geographic mobility is very low in Germany. In a given year, in the final sample, only about $1 \%$ of all SOEP respondents move.
} 


\section{Empirical Method and Results}

\subsection{Empirical Approach and Identification}

We run the following econometric model. To the extent that we use binary dependent variables, we run Linear Probability Models (LPM): $y_{i t}=\beta_{0}+\beta_{1}$ PostMarch $11_{i, 2011} \times 2011_{t}+\beta_{2}$ PostJune $30_{i, 2011} \times 2011_{t}$ $+\beta_{3}$ PostMarch $11_{i, 2011}+\beta_{4}$ PostJune $30_{i, 2011}+\mathrm{X}_{i t}{ }^{\prime} \gamma+\delta_{t}+\phi_{m}+\mu_{i}+\varepsilon_{i t}(1)$

where $y_{i t}$ is a dependent variable that measures the individual's mental well-being.

PostMarch $11_{i, 2011}$ is a dummy variable indicating whether a respondent's 2011 interview occurred before or March 11-the day of the Fukushima catastrophe. Note that this dummy is time invariant, i.e., all 2011 respondents who were interviewed after March 11 always have a one on this dummy, independent of when they were interviewed in the other years. In other words, this variable nets out all potentially existing systematic differences between respondents who were interviewed before and after March 11, 2011, respectively. Similarly constructed is PostJune $30_{i, 2011}$, which represents the day when the German parliament decided to permanently shut-down the 7 oldest German nuclear reactors and to phase out the remaining 8 ones before December 31, 2022.

The coefficients of the interaction terms between these two binary indicators and the year 2011, $\beta_{1}$ and $\beta_{2}$, yield the impact of these two dates on respondents' well-being.

The main identifying assumption here is that, conditional on year and month fixed effects, $\delta_{t}+\phi_{m}$, the individual-level covariates $\mathrm{X}_{i t}$, and conditional on netting out time-invariant individual unobservables, $\mu_{i}$, the interview date is random and unrelated to the Fukushima catastrophe. This is very likely the case since: 
(i) The nuclear meltdown happened on March 11, 2011. Most SOEP interviews are carried out during the first six months of a year. Roughly half of all respondents in 2011 , i.e. 5000 , conducted their interview before and after this date, respectively. In Table 1, we plot the mean values of all covariates along with the scale-free normalized difference. Imbens and Wooldridge (2009) suggest that a normalized difference above 0.25 indicates covariate imbalance. This is not the case for any of our covariates. Thus we conclude that the sample is well-balanced on observables. We do not find evidence for selection effects as a function of the March 11 cut-off interview date.

(ii) In around $50 \%$ of all cases, a trained interviewer is physically present when interviews are carried out. Typically, interviews are scheduled at least several days in advance. It is highly unlikely that the Fukushima accident itself had any impact on interview dates. March 11, 2011 was a Friday; the accident happened at 7:45am CEST (German) time. As a robustness check, we exclude all interviews where a trained interviewer was not present.

\section{[Insert Table 1 about here]}

Since the Fukushima disaster is exogenous to the German SOEP interview dates, in principle, no adjustment for pre-post differences in sample compositions is necessary. Basically, in a totally randomized setting, we could even rely on cross-sections to estimate the Fukushima effects. However, we are in the fortunate position to rely on panel data. This allows us to compare (i) LMP treatment effects unadjusted for observables with (ii) LMP treatment effects adjusted for observables as well as (iii) simple pooled LMP-OLS estimates not exploiting the panel structure with (iv) LMP-Fixed Effects (FE) estimates that eliminate time-invariant individual unobserved heterogeneity. Since, in our preferred model specifications, we focus on a short time horizon and compare survey responses in 2010 to those in 2011, it is unlikely that time-varying unobservables confound the FE estimates. 
Comparing (i) to (iv) against one another also serves as a test for the plausibility of the March 11 exogeneity assumption and yields information on potentially confounding impacts of observables as well as unobservables.

\subsection{Descriptive Findings}

Figures 2 to 4 anticipate and nicely illustrate our main findings. Figure 2 represents graphically our OLS model and Figures 3 and 4 represent our FE-model. The $x$-axis displays the interview date in 2011. The first black vertical bar indicates the Fukushima catastrophe and the second black bar the German Nuclear Phase-Out Bill. The latter permanently shut down the 7 oldest nuclear reactors and imposed a clear phase-out timeline for the remaining eight reactors.

Figures 2 and 3 plot daily averages in responses for EnvWorriesLarge. The difference between those two figures is the y-axis. In Figure 2, we simply plot the share of respondents, on a given day, who reported being very concerned about environmental protection. As seen, we observe a distinct jump in that share after March 11. After the German parliament passed the Nuclear Phase Out Bill, the share of environmentally concerned citizens went down again. Note that the grey underlined confidence intervals widen toward the end of the year since only about 1,100 interviews were carried out after August 1 , roughly $10 \%$ of all interviews.

In Figure 3, the y-axis makes use of the panel structure of the data and displays the individual-level difference in responses between the 2011 and 2010 interview. In other words, in Figure 3, we plot the change in the average daily share of people who are very concerned about the environment by their 2011 interview date, relative to their 2010 answers.

\section{[Insert Figure 2 to 4 about here]}

Figure 3 illustrates that, while there was zero change in environmental concerns before Fukushima's meltdown, after concerns significantly increased by 5 to 10 percentage points. After the conservative government announced their Nuclear Phase-Out Plan, thus making a U- 
turn with respect to their nuclear and climate change policies, environmental worries declined. ${ }^{3}$ Toward the end of the year, they leveled-off around the zero line, which indicates no significant changes in environmental concerns.

Figure 4 is set up analogously to Figure 3 , but plots changes in general life satisfaction. It is easy to see that the curve is almost flat around the zero $x$-line. No changes in life satisfaction that could be related to the meltdown or the change in German environmental policy are identifiable.

\subsection{Regression Results}

\subsubsection{Baseline Specifications}

Table 2 gives the results of the baseline specifications as outlined in equation (1). In our baseline specifications, we focus on the years 2010 and 2011. The first two columns of Table 2 estimate OLS-LMP and the next two columns FE-LPM models. ${ }^{4}$ Thus, the first two columns are the (covariate-adjusted) regression equivalent to Figure 2 and the next two columns the equivalent to Figure 3. The dependent variable is always EnvWorriesLarge and indicates the share of respondents who are "very concerned" about environmental protection. For the sake of clarity and brevity, we suppress the coefficient estimates of those covariates that are not of principle interest. As shown in the lower bottom of Table 2, in the even numbered columns, additional sample adjusting covariates, $\mathrm{X}_{i t}$, are included in the regressions, whereas they are excluded in the odd numbered columns.

\section{[Insert Table 2 about here]}

\footnotetext{
${ }^{3}$ Note that, in this graph, we plot both relevant Nuclear Phase Out Bill dates: the announcement of the bill on May 30 as well as the formal passing of the bill in the German parliament on June 30. It is not clear which of these two dates is the relevant one and was perceived as such by the citizens. It is likely that some parts of the population were more responsive to the first whilst others were more responsive to the second. In our main specifications, we decided to employ June 30 as the relevant date. However, the findings are largely robust to using May 30 as we show in our robustness check section.

${ }^{4}$ We routinely cluster standard errors at the household level. However, in our robustness checks, we show that clustering at the sate-level does not alter the findings (Bertrand et al., 2004).
} 
We learn the following from Table 2: First, across all fours models, we consistently find that environmental concerns significantly increased by 5-6 ppt. immediately after the Fukushima disaster. Relative to the pre-Fukushima baseline concern level, this represents an increase of about $20 \%$.

Second, after the abrupt switch in German nuclear policies-the permanent shut-down of the oldest German power plants and the ultimate phase-out of the remaining ones-concerns about environmental protection decreased significantly by about 9 ppt. Relative to the mean worry level between March 11 and June 30, which was 34\%, the estimates represent decreases in the share of environmentally distressed citizens by about $25 \%$, i.e., a decrease that roughly equals the increase immediately after Fukushima. Obviously, the German Nuclear Phase-Out Bill helped to counterbalance the mental distress triggered by Fukushima.

Third, overall, we find no evidence (i) that respondents differ in their observables pre vs. post the March 11 and June 30 interview dates; (ii) that the correction for observables makes any difference; or (iii) that the correction for unobservables matters. In all models, the coefficients remain almost identical whether or not we include $X_{i t}$. The OLS vs. FE estimates are likewise almost identical. Note that the small variation between OLS vs. FE coefficients may stem from the fact that the FE models are essentially identified by a two year balanced panel and individual-level changes in the variable of interest, whereas the OLS model is identified by a two year unbalanced panel. Thus, the OLS and FE samples are not identical; the OLS sample includes 6500 more observations from individuals who only participated in one of the two surveys waves. ${ }^{5}$

As discussed in Section 2.2, immediately after Fukushima the German government announced an "Atom-Moratorium" for 3 month during which the oldest German reactors were shut down and their safety rigorously inspected. One limitation of this study is that we cannot disentangle the "clean" Fukushima scaring effect from this immediate policy action effect. However, we do not believe that this hampers the interpretation of our findings for two

\footnotetext{
${ }^{5}$ This holds despite the fact that the number of observations included in the sample, as indicated in the bottom of Table 2, is identical.
} 
reasons: (1) In the aftermath of the disaster, most governments around the globe typically take some action-at least announce action in political speeches. In general, this makes it impossible to identify any natural disaster impact in a $100 \%$ clean way; and (2) if any, this particular immediate policy action by the German government should downward bias the impact of Fukushima on mental distress. In that case, we would obtain a lower bound estimate.

\subsubsection{Robustness Checks}

Table 3 provides a series of robustness checks, always employing our preferred fixed effects model in the last column of Table 2.

\section{[Insert Table 3 about here]}

As already mentioned in footnote 3 , in our standard specifications, we chose the date when the Nuclear Phase Out Bill formally passed the parliament (June 30). In column (1), we employ an alternative date, namely the date when the sharp turnaround in the government's energy policy was formally announced; May 30, 2011. As seen, our findings are robust to using the announcement instead of the implementation date.

In column (2), we include a linear time trend. One concern with the identification of the policy action effect may be that, after the sharp increase in concerns, concerns would have decreased even without the Nuclear Phase Out Bill. Column (2) shows that the identification of the effect is largely robust to the inclusion of a time trend.

Column (3) excludes people who moved recently and column (4) any postal interviews. The latter interviews may include measurement error in the interview date. In addition, respondents may have postponed the filling out of the questionnaire due to Fukushima. As seen, both effects are robust to both robustness checks.

Column (5) clusters standard errors at the state level (Bertrand et al., 2004) and column (6) balances the sample. Again, our findings are robust to these specifications. 
Finally, we use the years 2009 and 2010, our standard specification, but employ a placebo "After Meltdown" as well as a placebo "After Permanent Shutdown" date, namely March 11 and June 30, 2010. Both effects are close to zero in size and not statistically significant.

\subsubsection{Effect Heterogeneity}

Now we run more flexible specifications that investigate effect heterogeneity and yield additional reinforcing evidence for the plausibility of the estimates. Technically, in Table 3, we add the regressor we would like to stratify the sample on, both in levels and in interaction with the PostMarch $11_{i, 2011} \times 2011_{t}$ and the PostJune $30_{i, 2011} \times 2011_{t}$ covariates of interest. ${ }^{6}$ As seen in the column headers, we test effect heterogeneity with respect to: (a) distance to the next nuclear power plant, (b) political opinions, (c) risk aversion, (d) gender, and (e) age.

\section{Exploiting exogenous distances to nuclear reactors}

Column (1) formalizes econometrically what we see in Figure 1. In our preferred "distance to power plant" specification, we rely on a dummy that indicates if respondents live within $50 \mathrm{~km}(31 \mathrm{mi})$ distance to a nuclear power plant. $^{7}$ As the Appendix shows, $27 \%$ of all Germans do. This gives us enough statistical power and variation. Column (1) of Table 3 shows: First of all, people living closer to power plants do not worry more or less about the environment, i.e., we do not find evidence for geographical sorting. Note that, even if we found sorting, we would net out these systematic differences with this regressor. Especially in the short-run, the residential distance to the next nuclear power plant is exogenous with respect to Fukushima and the change in environmental policies. ${ }^{8}$

\footnotetext{
${ }^{6}$ We estimate these models by LMP and abstain from individual fixed effects. The reason is that all variables that we test are, by construction, very or totally time-invariant. This does not allow us to separately identify the triple interaction term effects from the level effects.

${ }^{7}$ The results are robust to alternate cut-off radii and available upon request.

${ }^{8}$ In a robustness check, we exclude people who moved since the last interview. In another robustness check, we test whether the results hold when one measures the distance of the place of birth to the next nuclear power plant. The results are stable and available upon request.
} 
Second, the plain PostMarch11 $1_{i, 2011} \times 2011_{t}$ and PostJune $30_{i, 2011} \times 2011_{t}$ coefficients remain robust in size and significance. Their triple interactions with "within50kmdistance" are small and not significantly different from zero. This means that there is no differential scaring or relieving effect of the meltdown and the phase out, depending on the respondents' distance to the next power plant. Obviously, all Germans were similarly affected by Fukushima and also similarly relieved. This makes sense since a potential nuclear disaster would, due to the small distances, certainly significantly affect all Germans, independent of where they live.

\section{[Insert Table 4 about here]}

In extended analyses not displayed, we stratify by the following three measures: (a) whether the closest nuclear power plant had been shut down, (b) whether the closest nuclear power plant will be shut down until 2020, (c) whether the closest nuclear power plant will not be shut down (exploiting the fact that some Germans live in close distance to nuclear power plants in France and Switzerland which have not been affected by German policy action). However, the results confirm the finding above according to which distance to a power plant does not matter. ${ }^{9}$

\section{Political opinion and risk aversion}

Column (2) makes use of SOEP questions about respondents' political opinions and party preferences. We group those together who indicate a strong preference for the Greens and the Social Democrats; both parties formed a centre-left coalition between 1998 and 2005 and were largely in favor of a permanent nuclear phase-out, long before Fukushima. It turns out that people in favor of "Red-Green" are 12ppt. more likely to be "very concerned" about environmental protection. With regard to the Fukushima disaster, we do not find much evidence that people who strongly sympathize with the political ideas of Red-Green reacted differently to the disaster.

\footnotetext{
${ }^{9}$ The detailed results are available upon request.
} 
In column (3), we test whether risk aversion matters. Standard economic theory would clearly suggest that it does, since a nuclear accident is a small probalistic event with high social costs. Indeed we do find evidence that risk aversion mattered for the evaluation of the phaseout decision; risk averse people seem to have incurred an additional 3\% Fukushima scaring "premium", significant at the $5 \%$ level. Similarly, they seem to have been more relieved after the permanent phase out had been decided, although the latter estimate is not statistically significant.

\section{Gender and age}

Column (4) examines the role of gender. We find clear and strong evidence that women in general are (i) 5 ppt. more likely to be very concerned about environmental protection; (ii) incurred a 3ppt. larger scaring effect after the meltdown; and (iii) a 8ppt. larger relieving effect after the phase-out as compared to men.

Finally, we look at age. The Greens were elected into the German parliament for the first time in 1982. They are still seen as the democratic representation of the 1968er movement in Germany, a left-wing, student-driven, intellectual movement. One of the Greens' main political goals was the (immediate) phase-out of nuclear energy and the transition to renewables - this objective became part of their identity after the Chernobyl nuclear disaster in 1986 . We generate an age dummy "above50" identifying respondents who were at least 25 in 1986, i.e. who experienced Chernobyl, the (post) 1968 movement, and the intense debates about nuclear energy in the 1980s. However, we do not find much evidence that respondents over 50 reacted differently to the disaster than the younger generation.

One can summarize that the Fukushima scaring and phase-out relieving effects are mostly driven by risk averse women. 


\section{Alternative Mental Well-Being Measures}

\section{General life satisfaction}

The models in Table 4 make use of alternative mental well-being measures. The first column uses the standard 11 categorical life satisfaction measure as dependent variable. This model is the regression equivalent to Figure 4. And as already suspected in Figure 4, we do not find any evidence that Fukushima or the Phase-Out Bill had an impact on citizens' general life satisfaction. Typically, studies consistently find that individual economic prospect or unemployment have a strong impact on life satisfaction (Winkelmann and Winkelmann, 1998; Frijters et al. 2004; Kassenboehmer and Haisken-DeNew, 2009; Knabe et al., 2010). One may interpret our finding as evidence that disasters (in other countries) may affect specific mental well-being measures even in locations geographically far away, but not life satisfaction in general, at least as long as people are not directly personally affected.

\section{Affective well-being measures}

The finding from column (1) is reinforced in column (2) where we make use of a collapsed version of the "happy" affective well-being measure (see Section 3.2). We do not find evidence that the share of people who felt happy "very often" or "often" in the last 4 weeks varied significantly.

\section{[Insert Table 5 about here]}

In contrast, immediately after Fukushima, the share of respondents who felt "sad" increased by about 4ppt (column (3)). Part of the reason why Fukushima has been considered so disastrous was the lack of or misleading catastrophe management by both politicians-officials underestimated dangers and knowingly concealed information-and the operating Tokyo Electric Power Company (TEPCO). Media reports about these failures made environmentallyconcerned people around the globe very sad and angry. This is illustrated in column (3). We see that the sadness-level substantially shifted upward after Fukushima. 


\section{Concerns about climate change}

The radical change in German conservative energy politics entailed a long-term large-scale plan under which Germany would gradually replace nuclear energy with renewables. The government of Angela Merkel generated its own term for this ambitious plan: "EnergyChange" (Energiewende). Since the Energiewende is inherently linked to climate change politics and was largely communicated to the public with that spin, we test whether Germans' concerns about climate change changed too.

Column (5) shows that concerns about climate change significantly increased after Fukushima and decreased after the announcement of the new German energy politics and the Energiewende. ${ }^{10}$

\subsubsection{Long-Run Effects}

Table 6 tests long-run effects. We intend to test whether concerns about environmental protection increased significantly in the long-run due to Fukushima. For this purpose, we restrict the sample to the years 2009 and 2012 and, again, estimate (unbalanced) OLS and (balanced) FE models. When estimating effects over a longer time horizon, we face a trade-off between considering unobservables through individual fixed effects and considering marginal populations who did not participate at least once pre- and post-Fukushima in the survey. For example, for the two years 2009 and 2012, we have a total pool of 31,456 person-year observations from 22,942 different individuals, but only 8,761 of them participated in both 2009 and 2012. While the OLS model is identified by all 22,942 respondents, the FE model only makes use of the 8,761 long-term SOEP participants.

In all columns, we estimate a model as in equation (1). Column (1) uses an unbalanced panel and estimates an OLS model while column (2) employs a fixed effect model using a balanced panel. Columns (3) and (4) only makes use of the years 2009 and 2012 and basically

\footnotetext{
${ }^{10}$ There are several explanations for why climate change concerns significantly increased after Fukushima: (1) It could simply be that the environmental disaster raised people's awareness about environmental issues; (2) In the short run, shutting down nuclear power meant replacing the energy production largely with climate-damaging coal energy; and/or (3) People might confuse that nuclear power and emissions have not been linked to climate change.
} 
compares environmental concern level effects in 2009 to those in 2012. In all four models, the 2012 effect is identified by the year dummy 2012.

\section{[Insert Table 6 about here]}

We find that (i) in the first two columns, the standard Fukushima scaring and phase out relieving effects are very close to our standard estimates in Table 2, which are only based on 2010 and 2011; (ii) that the OLS and FE estimates in the first two columns are almost identical; and (iii) the 2012 effects is always small; for the unbalanced OLS models in columns (1) and (3) that include marginal populations, we find a small, but significant, 1 ppt. increase in concerns levels for 2012. However, this small significant effect vanishes once we net out individual unobserved heterogeneity and run fixed effects regressions.

All four findings reinforce the credibility of our estimates. The last finding (iii) shows that the policy action Phase-Out Bill effect indeed offset, at least almost entirely offset, the increased environmental concerns after Fukushima.

\subsubsection{Comparison to Long-Run Effects of the Chernobyl Disaster:}

Next, as a last exercise, we run our standard model but estimate the effects of the Chernobyl disaster on being mentally very concerned about environmental protection. More specifically, we replicate Table 6 using the Chernobyl disaster in 1986 in order to assess its long-term impact on environmental worries in the German population. This serves as a robustness check for the Nuclear Phase Out Effect that we identify above and which significantly reduced concerns about environmental protection.

\section{[Insert Table 7 about here]}

In the first two columns of Table 7 we basically replicate the first two columns of Table 6 , but use SOEP data for the years 1984 to 1987 and April 28, 1986 as the "Chernobyl meltdown" date. ${ }^{11}$ As seen, after Chernobyl, the share of SOEP respondents who were "very concerned

\footnotetext{
${ }^{11}$ Although the Chernobyl disaster happened on the evening (EST) of April 26, it took until April 28 before the media reported about the disaster.
} 
about environmental protection" increased by a highly significant 11 ppt. Relative to the mean worry level before Chernobyl ${ }^{12}$, this represents an increase of about 25 percent-almost exactly the same increase in mental distress that we find after Fukushima. Thus, we argue that the two events are comparable; particularly since we always focus on Germany and use the same dataset as well as the same variables.

Besides the fact that the worries increased by the same share after Fukushima as compared to Chernobyl, the coefficient for 1987 is of roughly the same size and highly significant as well. This means that-in contrast to Fukushima-after Chernobyl we seem to observe a persistent jump in mental distress due to environmental worries. We investigate this hypothesis further in columns (3) and (4), where we add the years 1988 and 1989 to the model.

Column (3) estimates an OLS model using the pooled data and column (4) employs a balanced fixed-effects model. First, it is noteworthy that the identified coefficient postApril28 $8_{i, 1986} * 1986$ remains surprisingly robust across all four models in columns (1) to (4). This reinforces the exogeneity assumption of the Chernobyl disaster. Second, we find that the share of Germans who were very concerned about environmental protection indeed persistently increased by a large share after Chernobyl. The coefficients for the three postChernobyl yearly dummies 1987, 1988, and 1989 are large and highly significant.

\section{[Insert Figure 5 about here]}

Finally, we non-parametrically illustrate the persistent increase in environmental concerns in Figure $5 .{ }^{13}$ In the visual analogue to the model in column (3) it is easy to see that concerns substantially increased after Chernobyl and remained on this elevated level. This finding reinforces one of the main findings of this paper suggesting that it was indeed the German

\footnotetext{
${ }^{12}$ which was 40 percent and thus significantly higher than it is today.

${ }^{13}$ Again, as in Figure 2, a report daily averages. However, since we plot the daily means over several years and since most respondents are interviewed in the first months of a year, we observe some jumps in the graph. To smooth them a little bit, we disregarded days with less than five respondents interviewed.
} 
Nuclear Phase Out Bill of 2011 that significantly reduced environmental concerns after Fukushima.

\section{Discussion and Conclusion}

This research shows that environmental disasters can have significant negative spillover effects on the mental health of another country's residents-even if the other country is on the other side of the world and the disaster does not directly affect its residents, nor does it increase the likelihood that a similar disaster occurs on the other country.

The Fukushima disaster in March 2011 and its subsequent related events significantly increased concerns about environmental protection among the German population. The mental scaring effects were reversed when the hitherto pro-nuclear governing centre-right coalition fundamentally changed its position and energy policy. On June 30, the German parliament voted almost unanimously for a law that permanently shut-down the 7 oldest German nuclear power plants and implemented a clear phase-out plan for the remaining 8 by the end of 2022 . The Nuclear Phase-Out Bill has been combined with a large scale government program supporting the transition to renewables ("Energiewende"). With this bill, Germany became the first nuclear energy generating country to completely phase-out its use. We show that this policy U-turn-supported by a large majority of Germans-improved citizens' mental wellbeing, particularly among risk-averse women.

We find particularly strong effects on citizens' concerns about the environment, but also on affective well-being measures such as sadness. Mental health is a multidimensional concept that is complex to measure. Strong concerns or worries are integral part of overall mental health. When we correlate our "very concerned about environmental protection" measure with the mental health SF12 summary scale (RAND, 1995), which was surveyed in the SOEP in 2010, we find that people who are very concerned about the environment have a highly significantly $1.8 \mathrm{ppt}$ lower mental health status. Thus it is reasonable to assume that people who are permanently very concerned about the environment lose $1 \%$ of a Quality Adjusted Life Year (QALY). This assumption allows us to carry out the following rough back-of-the-envelope 
calculation: Fukushima increased the share of "very concerned" Germans by 6ppt. This equals about 4 million German citizens. ${ }^{14}$ It took roughly 3 months for the German parliament to implement measures that ameliorated environmental concerns. Thus one would obtain a monetized mental health loss of $0.01 * 4 / 4=100,000$ QALYs. The health economics literature values one QALY with roughly $100,000 €$. Thus, this would yield a total monetized Fukushimarelated mental health loss of $€ 1$ bn or $€ 250$ per affected citizen, which equals about $€ 20$ per week and affected citizen.

There is complementary evidence showing that people are actually willing to pay for nuclear-free energy production, most likely in return for a lower environmental concern level. In polls, $70 \%$ of the German citizens say that they would be willing to pay higher energy prices as a consequence of the transition to renewables (Infratest Dimap, 2011b). Actually, part of the Energiewende policy is a fixed subsidy for every kilowatt hour (kWh) produced by renewables („Einspeisevergütung“). The total $€ 18 \mathrm{bn}$ annual cost of this policy is paid by all electricity consumers through a flexible absolute tax per kWh („EEG-Umlage“). ${ }^{15}$ In 2013, this tax amounted to 5.3 Eurocent per kWh (Bundesregierung, 2013). The average household consumes about $3500 \mathrm{kWh}$ per year and thus pays $€ 185$ or $€ 15$ per months for the transition to renewables (EnergieAgentur NRW, 2012). While this represents a mandatory tax, which must be paid by all citizens, a study by Check24 (2012) finds that, before Fukushima, 37\% of consumers switching their energy provider, chose renewable energy sourced electricity. Immediately after Fukushima, this share doubled to $74 \%$ and was still $64 \%$ one year after the disaster (Check24, 2013).

This illustrates that natural disasters and catastrophes may not only have external effects on the mental well-being of other country citizens, but may also impact people's actual economic behavior, which is in this case presumably driven by fear and mental concerns. How

\footnotetext{
${ }^{14}$ According to the German Federal Statistical Office (2012), 68.6 million German citizens were about 18 in 2012. Thus, 1ppt. equals 686,000 people and 6ppt. roughly 4 million.

${ }^{15}$ Meanwhile, the German law being the role model, at least 65 states around the globe have copied this subsidy for renewables (REN21, 2013).,
} 
mental concerns translate into changes in actual economic behavior and individuals' actions is a promising future research field.

\section{Literature}

Andersen, H. H., Mühlbacher, A., Nübling, M., Schupp, J., and Wagner, G. G. (2007): "Computation of standard values for physical and mental health scale scores using the SOEP version of sf12v2." Journal of Applied Social Science Studies (Schmollers Jahrbuch), 127, 171182.

Aoki, M.; Rothwell, G. (2013): "A comparative institutional analysis of the Fukushima nuclear disaster: Lessons and policy implications", Energy Policy, 53(C): 240-247.

Berger, E. M. (2010): "The Chernobyl Disaster, Concern about the Environment, and Life Satisfaction", Kyklos, 63(1): 1-8.

Bertrand, M.; Duflo, E.; Mullainathan, S. (2004): "How Much Should We Trust Differences-inDifferences Estimates?" The Quarterly Journal of Economics, 119(1): 249-275.

Bundesregierung (2011a): Regierungserklärung von Bundeskanzlerin Angela Merkel ("State of the Union Address of Chancellor Angela Merkel"), June 9, 2011: http://www.youtube.com/watch?v=jFm1l 1Q3Ug, last accessed on July 2, 2013.

Bundesregierung (2011b): Bundesregierung setzt Laufzeitverlängerung für drei Monate aus: http://www.bundesregierung.de/Content/DE/Artikel/2011/03/2011-03-14-moratoriumkernkraft-deutschland.html, last accessed on July 2, 2013.

Bundesregierung (2011c): Regierungspressekonferenz vom $1 . \quad$ Juni: http://www.bundesregierung.de/Content/DE/Mitschrift/Pressekonferenzen/2011/05/2011-0601-regpk.htmlx, last accessed on July 2, 2013.

Bundesregierung (2011d): Bundespräsident unterschreibt Änderung des Atomgesetzes: http://www.bundesregierung.de/Content/DE/Artikel/2011/06/2011-06-06-Schrittweiser\%20-

Atomausstieg.html, last accessed on July 2, 2013.

Bundesregierung (2011e): Pressekonferenz zum Energiekonzept der Bundesregierung mit Bundeskanzlerin Merkel, BM Rösler, BM Röttgen und BM Ramsauer: http://www.bundesregierung.de/Content/DE/Mitschrift/Pressekonferenzen/2011/05/2011-0530-pk-bk-bm-energiekonzept.html, last accessed on July 2, 2013.

Bundesregierung (2013): Energiekonzept, http://www.bundesregierung.de/Content/DE/Artikel/2013/07/2013-07-08-reform-derphotovoltaik-foerderung-erfolgreich.html, last accessed on July 10, 2013. 
Buesseler, K. O.; Jayne, S. R., Fisher, N. S.; Rypina, I. I.; Baumann, H.; Baumann, Z.; Breier, C. F.; Douglass, E. M.; George, J.; Macdonald, A. M.; Miyamoto, H.; Nishikawa, J.; Pike, S. M.; Yoshida, S. (2013): "Fukushima-derived radionuclides in the ocean and biota off Japan", Proceedings of the National Academy of Sciences, forthcoming.

Cahit, G.; Senik, C.; Stichnoth, H. (2012): “You can't be happier than your wife. Happiness gaps and divorce", Journal of Economic Behavior \& Organization, 82(1): 110-130.

Check24 (2012): Ein Jahr nach Fukushima: 64 Prozent der Stromwechsler wählten im Februar 2012 Ökostrom-Tarif, http://www.check24.de/files/p/2012/e/c/7/180 2012-03-

12 check24 pm oekostrom entwicklung nach fukushima.pdf, last accessed on July 10, 2013.

Clark, A. E.; Senik, C. (2010): "Who Compares to Whom? The Anatomy of Income Comparisons in Europe", Economic Journal, 120(544): 573-594.

Clark, A. E.; Etilé, F. (2011): "Happy house: Spousal weight and individual well-being", Journal of Health Economics, 30(5): 1124-1136.

Clark, A. E.; Frijters, P.; Shields, M. A. (2008): "Relative Income, Happiness, and Utility: An Explanation for the Easterlin Paradox and Other Puzzles", Journal of Economic Literature, 46(1): 95-144.

Clark, A. E.; Kristensen, N.; Westergård-Nielsen, N. (2009): "Job Satisfaction and Co-worker Wages: Status or Signal?”, Economic Journal, 119(536): 430-447.

Clark, A. E.; Knabe, A.; Rätzel, S. (2010): “Boon or bane? Others' unemployment, well-being and job insecurity”, Labour Economics, 17(1): 52-61.

Csereklyei, Z. (2013) Measuring the Impacts of Nuclear Accidents on Energy Policy. Department of Economics Working Paper Series, 151. WU Vienna University of Economics and Business, Vienna.

Danzer, A. M.; Danzer, N. (2011): "The Long-Term Effects of the Chernobyl Catastrophe on Subjective Well-Being and Mental Health", IZA Discussion Papers 5906.

Deaton, A. (2012): "The financial crisis and the well-being of Americans", Oxford Economic Papers, 64(1): 1-26.

Dohmen, T.; Falk, A.; Huffman, D.; Sunde, U.; Schupp, J.; Wagner, G. G. (2010): “Individual Risk Attitudes: New Evidence from a Large, Representative, Experimentally-Validated Survey", Journal of the European Economic Association, 9(3): 225-250

Draca, M.; Machin, S.; Witt, R. (2011): "Panic on the Streets of London: Police, Crime, and the July 2005 Terror Attacks," American Economic Review, 101(5): 2157-2181. 
EnergieAgentur NRW (2012): Erhebung „Wo im Haushalt bleibt der Strom? Anteile, Verbrauchswerte und Kosten von 12 Verbrauchsbereichen in 1- bis 6-Personen-Haushalten," http://www.energieagentur.nrw.de/ database/ data/datainfopool/erhebung wo bleibt der strom.pdf, last accessed on July 10, 2013.

Ethikkommission (2011): Deutschlands Energiewende - Ein Gemeinschaftswerk für die Zukunft: http://www.bundesregierung.de/Content/DE/ Anlagen/2011/07/2011-07-28-abschlussberichtethikkommission.pdf, last accessed on July 2, 2013.

Frank, R.G. (1981): “Cost Benefit Analysis in Mental Health: A Review of the Literature", Administration in Mental Health, 8(3):161-176, 1981

Frank, R.G.; Koss C. (2005): "Mental Health and Labor Markets Productivity Loss and Restoration, in Disease Control Priorities Project." Geneva, Switzerland: World Health Organization

Frey, B. S.; Luechinger, S.; Stutzer, A. (2007): "Calculating Tragedy: Assessing The Costs Of Terrorism", Journal of Economic Surveys, 21(1): 1-24, 02.

Frick, J. R., Ziebarth, N.R. (2013): "Welfare-Related Health Inequality: Does the Choice of Measure Matter?" The European Journal of Health Economics, 14(3): 431-442.

Frijters, P.; Haisken-DeNew, J. P.; Shields, M. A. (2004): "Money Does Matter! Evidence from Increasing Real Income and Life Satisfaction in East Germany Following Reunification", American Economic Review, 94(3): 730-740.

Gesundheitsberichterstattung des Bundes (2012), www.gbe-bund.de, last accessed on June 20, 2012.

German Federal Statistical Office (2012): Statistisches Jahrbuch 2012, Statistisches Bundesamt, https://www.destatis.de/DE/Publikationen/StatistischesJahrbuch/StatistischesJahrbuch.html, last accessed on July 10, 2013.

Glaser, Alexander (2011): "After Fukushima: Preparing for a More Uncertain Future of Nuclear Power", The Electricity Journal, 24(6): 27-35.

Glied, S. A.; Frank, R.G. (2009): "Better But Not Best: Recent Trends in the Well Being of the Mentally III", Health Affairs, 28(3): 637-648.

Hippel, Frank N. (2011): "The radiological and psychological consequences of the Fukushima Daiichi accident", Bulletin of the Atomic Scientists, 67(5): 27.

Hommerich, C. (2012). "Trust and Subjective Well-being after the Great East Japan Earthquake, Tsunami and Nuclear Meltdown: Preliminary Results." International Journal of Japanese Sociology, 21(1): 46-64. 
Huenteler, J.; Schmidt, T. S.; Kanie, N. (2012): "Japan's post-Fukushima challenge - implications from the German experience on renewable energy policy", Energy Policy, 45(C): 6-11.

IAEA (2011a): Fukushima Nuclear Accident Update Log: http://www.iaea.org/newscenter/news/2011/fukushima110311.html, last accessed on July 2, 2013.

IAEA (2011b): International Nuclear and Radiological Event Scale (INES): www.iaea.org/Publications/Factsheets/English/ines.pdf, last accessed on July 2, 2013.

Imbens, Guido W.; Wooldridge, Jeffrey M. (2009): "Recent Developments in the Econometrics of Program Evaluation", Journal of Economic Literature, 47(1): 5-86.

Infratest Dimap (2010): Bundesweite Umfragen, August 2010, http://www.infratestdimap.de/umfragen-analysen/bundesweit/ard-deutschlandtrend/2010/august/, last accessed on July 2, 2013.

Infratest Dimap (2011a): Bundesweite Umfragen, Deutschlandtrend Juni 2011, http://www.infratest-dimap.de/umfragen-analysen/bundesweit/arddeutschlandtrend/2011/juni/, last accessed on July 2, 2013.

Infratest Dimap (2011b): Bundesweite Umfragen, ARD DeutschlandTREND, März 2011 extra: Atom-Katastrophe in Japan: http://www.infratest-dimap.de/umfragenanalysen/bundesweit/ard-deutschlandtrend/2011/maerz-extra/, last accessed on July 2, 2013.

Infratest Dimap (2011c): Bundesweite Umfragen, March 15-16, 2011, http://www.infratestdimap.de/umfragen-analysen/bundesweit/umfragen/aktuell/aussetzung-derlaufzeitverlaengerung-gilt-nicht-als-glaubwuerdiger-kurswechsel/, last accessed on July 2, 2013. Institute of Nuclear Power Operations (INPO) (2011): Special Report on the Nuclear Accident at the Fukushima Daiichi Nuclear Power Station, http://www.nei.org/filefolder/11 005 Special Report on Fukushima Daiichi MASTER 1108 11 1.pdf, last accessed May 27, 2013.

Ishino, T.; Ogaki, M.; Kamesaka, A.; Murai, S. (2012): "Higashi Nihon Daishinsai no Kôfukukan he no Eikyô (The Impact of the Great East Japan Earthquake on Happiness)." In M. Seko, H. Teruyama, I. Yamamoto, \& Y. Higuchi (Eds.), "Nihon no Kakeikoudou no Dainamizumu: HigashiDaishinsai ga Kakei ni ataeta Eikyo [Dynamism of Household Bevior in Japan: The Effects of the Great East Japan Earthquake on the Households]"; pp. 255-272, Vol. 8. Tokyo: Keio University Press.

Kassenboehmer, S. C.; Haisken-DeNew, J. P. (2009): "You're Fired! The Causal Negative Effect of Entry Unemployment on Life Satisfaction", Economic Journal, 119(536): 448-462. 
Kawashima, S.; Takeda, F. (2012): "The effect of the Fukushima nuclear accident on stock prices of electric power utilities in Japan", Energy Economics, 34(6): 2029-2038.

Knabe, A.; Rätzel, S.; Schöb, R.; Weimann, J. (2010): "Dissatisfied with Life but Having a Good Day: Time-use and Well-being of the Unemployed", Economic Journal, 120(547): 867-889.

Knabe, A.; Rätzel, S. (2011): "Scarring or Scaring? The Psychological Impact of Past Unemployment and Future Unemployment Risk", Economica, 78(310): 283-293.

Lu, C.; Frank, R.G.; Liu, Y.; Shen. J. (2009): "The impact of mental health on labour market outcomes in China", Journal of Mental Health Policy and Economics, 12(3): 157-166.

Luechinger, S.; Raschky, P. A. (2009): "Valuing flood disasters using the life satisfaction approach", Journal of Public Economics, 93(3-4): 620-633.

Luechinger, S.; Meier, S.; Stutzer, A. (2010): “Why Does Unemployment Hurt the Employed?: Evidence from the Life Satisfaction Gap Between the Public and the Private Sector", Journal of Human Resources, 45(4): 998-1045.

Metcalfe, R.; Powdthavee, N.; Dolan, P. (2011): "Destruction and Distress: Using a Quasi-Experiment to Show the Effects of the September 11 Attacks on Mental Well-Being in the United Kingdom", Economic Journal, 121(550): F81-F103.

REN21: Renewable Energy Policy Network for the $21^{\text {st }}$ Century (2013): Renewables 2013: Global Status Report, http://www.ren21.net/REN21Activities/GlobalStatusReport.aspx, last accessed on July 10, 2013.

Ojeda, V.D.; Frank, R.G.; McGuire, T.G.; Gilmer, T.P. (2010): “Mental Illness, Nativity, Gender and Labor Supply", Health Economics, 19(4): 396-421.

Oswald, A. J. (1997): "Happiness and Economic Performance", Economic Journal, 107(445): 1815-1831.

Oswald, A. J.; Wu, S. (2011): "Well-Being across America", The Review of Economics and Statistics, 93(4): 1118-1134.

RAND (1995): "User's Manual for the Medical Outcomes Study (MOS) Core Measures of HealthRelated Quality of Life (by Hays, R. D., Sherbourne, C. D, Mazel, R.)." RAND Monograph Report, Santa Monica, RAND Corporation.

http://www.rand.org/pubs/monograph reports/MR162.html, last accessed on February 2, 2013.

Reaktorsicherheitskommission (2011): Anlagenspezifische Sicherheitsüberprüfung (RSK-SÜ) deutscher Kernkraftwerke unter Berücksichtigung der Ereignisse in Fukushima-I (Japan): http://www.rskonline.de/downloads/rsk sn sicherheitsueberpruefung 20110516 hp.pdf, last accessed on July 2, 2013. 
Rehdanz, K.; Welsch, H.; Narita, D.; Okubo, T. (2013): "Well-being effects of a major negative externality: the case of Fukushima", Kiel Working Papers 1855.

Rieu, A.-M. (2013): "Thinking after Fukushima. Epistemic shift in social sciences", Asia Europe Journal, 11(1): 65-78.

Schüller, S. (2012): "The Effects of 9/11 on Attitudes Toward Immigration and the Moderating Role of Education", IZA Discussion Papers 7052.

Senik, C. (2009): "Direct evidence on income comparisons and their welfare effects", Journal of Economic Behavior \& Organization, 72(1): 408-424.

Socio-Economic Panel (SOEP): Data for years 1984-2011, version 28, SOEP, 2012, doi: 10.5684/soep.v28.

Spiegel (2011): Chronologie der Katastrophe in Fukushima I (Daiichi): http://www.spiegel.de/flash/flash-25484.html, last accessed on July 2, 2013.

Stern (2011): Super-GAU in Fukushima: Chronologie der Atomkatastrophe: http://www.stern.de/panorama/super-gau-in-fukushima-chronologie-der-atomkatastrophe-

1797583.html, last accessed on July 2, 2013.

Tiefenbach, T.; Kohlbacher, F. (2013): "Happiness from the Viewpoint of Economics: Findings from Recent Survey Data in Japan", German Institute for Japanese Studies, Working Paper 13/1.

Thomas, S. (2012): “What will the Fukushima disaster change?" Energy Policy, 45(C): 12-17.

Uchida, Y.; Takahashi, Y.; Kawahara, K. (2011): “Higashi Nihon Daishinsai chokugo no Jakunensô no Seikatsukôdô oyobi Kôfukudo ni taisuru Eikyo (The Impact of the Great East Japan Earthquake on the Behavior and Happiness of Young People)"; New ESRI Working Paper 24.

Vivoda, V. (2012): “Japan's energy security predicament post-Fukushima", Energy Policy, Elsevier, 46(C): 135-143.

Wagner, G. G., Frick, J. R., Schupp, J. (2007): “The German Socio-Economic Panel Study (SOEP) Evolution, Scope and Enhancements." Journal of Applied Social Science Studies (Schmollers Jahrbuch), 127(1): 139-169.

Wang, Q.; Xi, C.; Xu, Y.-C. (2013): "Accident like the Fukushima unlikely in a country with effective nuclear regulation: Literature review and proposed guidelines", Renewable and Sustainable Energy Reviews, 17(C): 126-146.

WHO (2013): Health risk assessment from the nuclear accident after the 2011 Great East Japan earthquake and tsunami, based on a preliminary dose estimation, Report http://www.who.int/ionizing radiation/pub meet/fukushima risk assessment 2013/en/index .html, last accessed on May 17, 2013. 
Winkelmann, L.; Winkelmann, R. (1998): "Why Are the Unemployed So Unhappy? Evidence from Panel Data", Economica, 65(257): 1-15.

Yamamura, E. (2012): "Experience of technological and natural disasters and their impact on the perceived risk of nuclear accidents after the Fukushima nuclear disaster in Japan 2011: A cross-country analysis", The Journal of Socio-Economics, 41(4): 360-363.

Zeit (2011): Fukushima: Chronik des Versagens, http://www.zeit.de/2012/10/Fukushima, last accessed on July 2, 2013. 


\section{Figures and Tables}

Figure 1: Nuclear Power Plants and (Temporary) Nuclear Waste Sites: Distances to SOEP Respondents

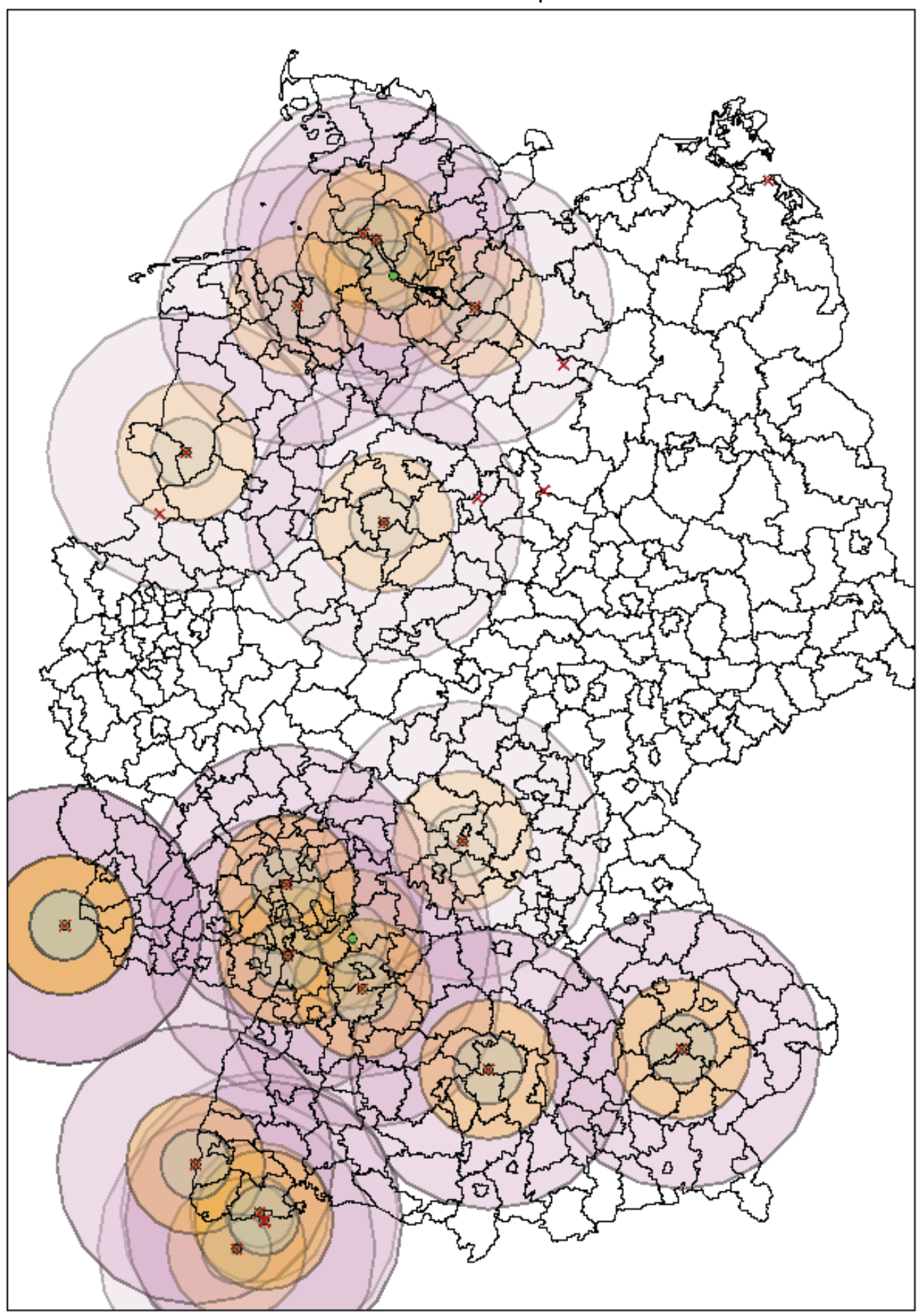

Notes: Circles indicate 25, 50, and $100 \mathrm{~km}$ radii. Dots indicate nuclear power plants; crosses indicate (temporary) nuclear waste sites. 
Figure 2: Share of SOEP Respondents Who Are Very Concerned About Environmental Protection Very Concerned About Environmental Protection

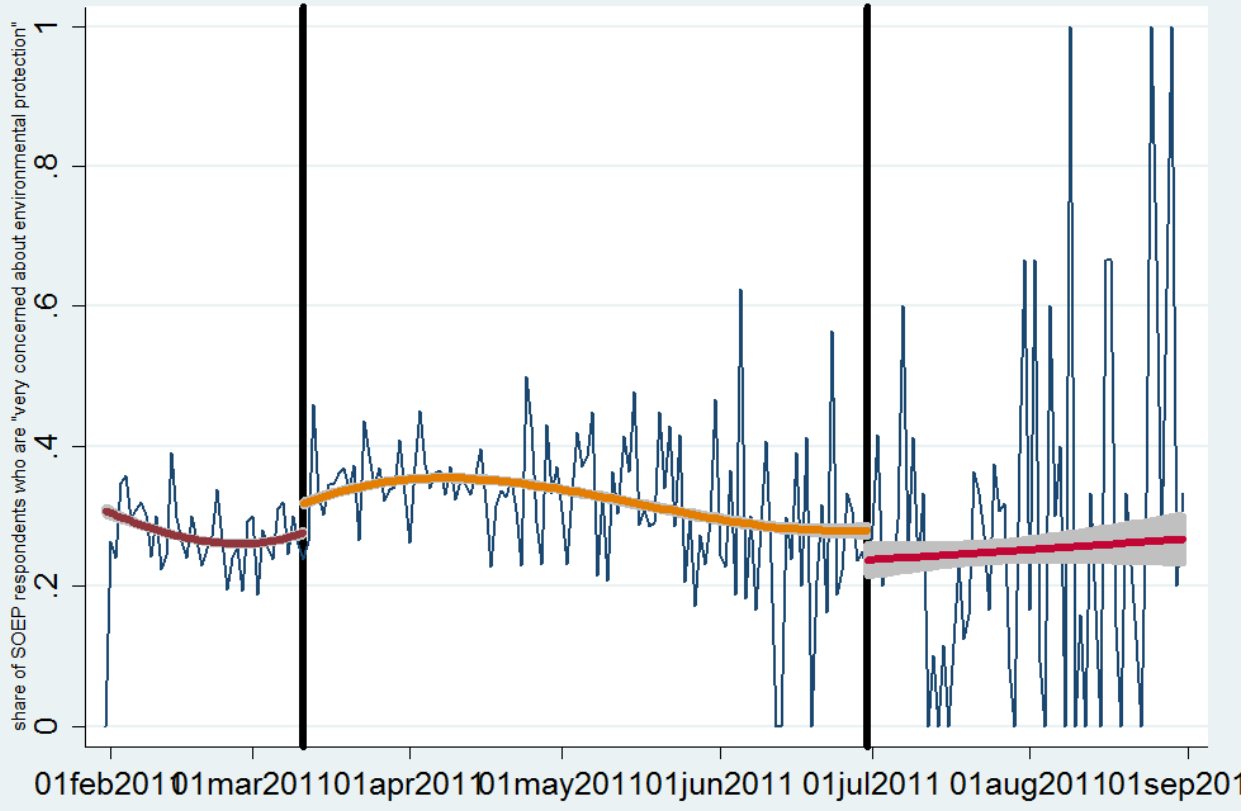

Figure 3: SOEP Respondents Who Are Very Concerned About Environmental Protection (first difference, 2011 vs. 2010)

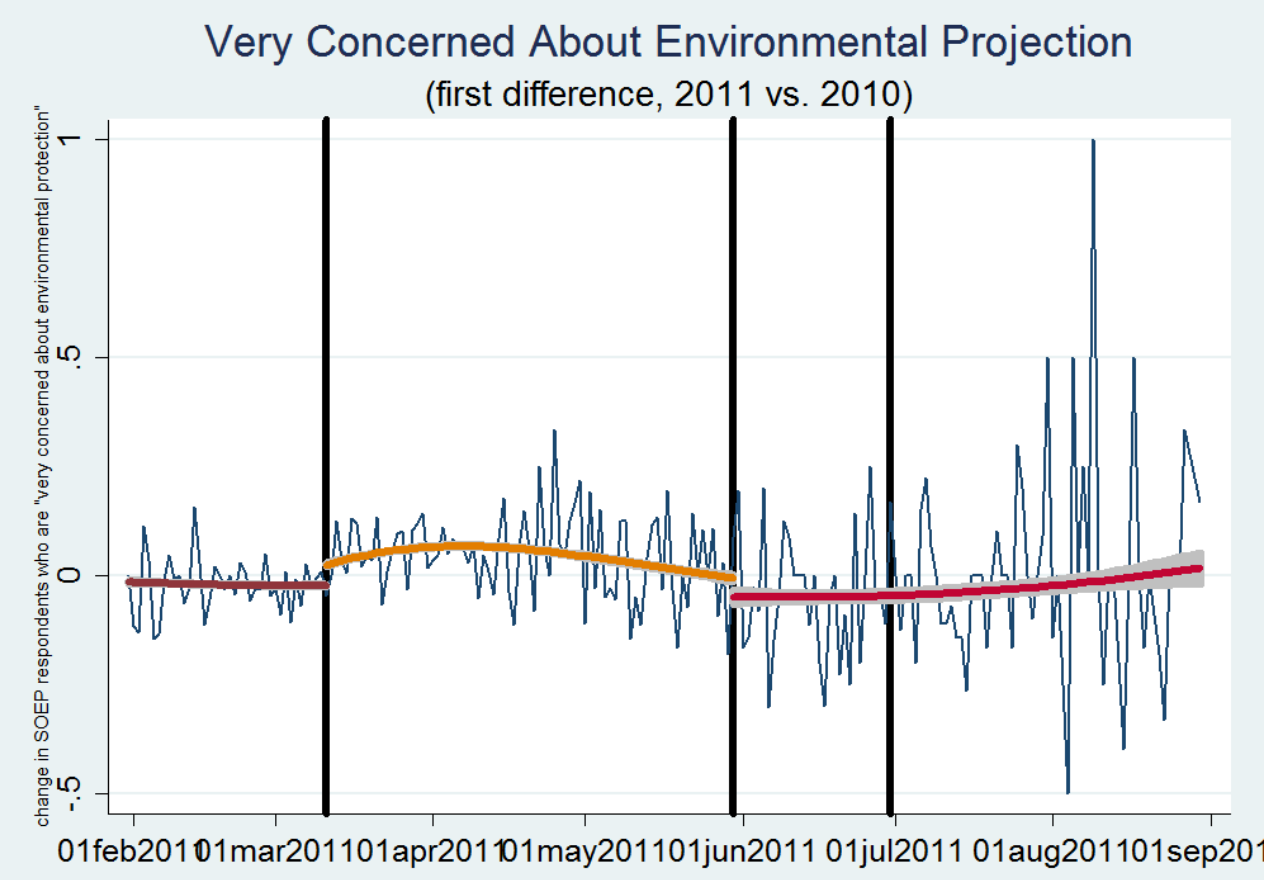


Figure 4: Reported Life Satisfaction of SOEP Respondents (first difference, 2011 vs. 2010)

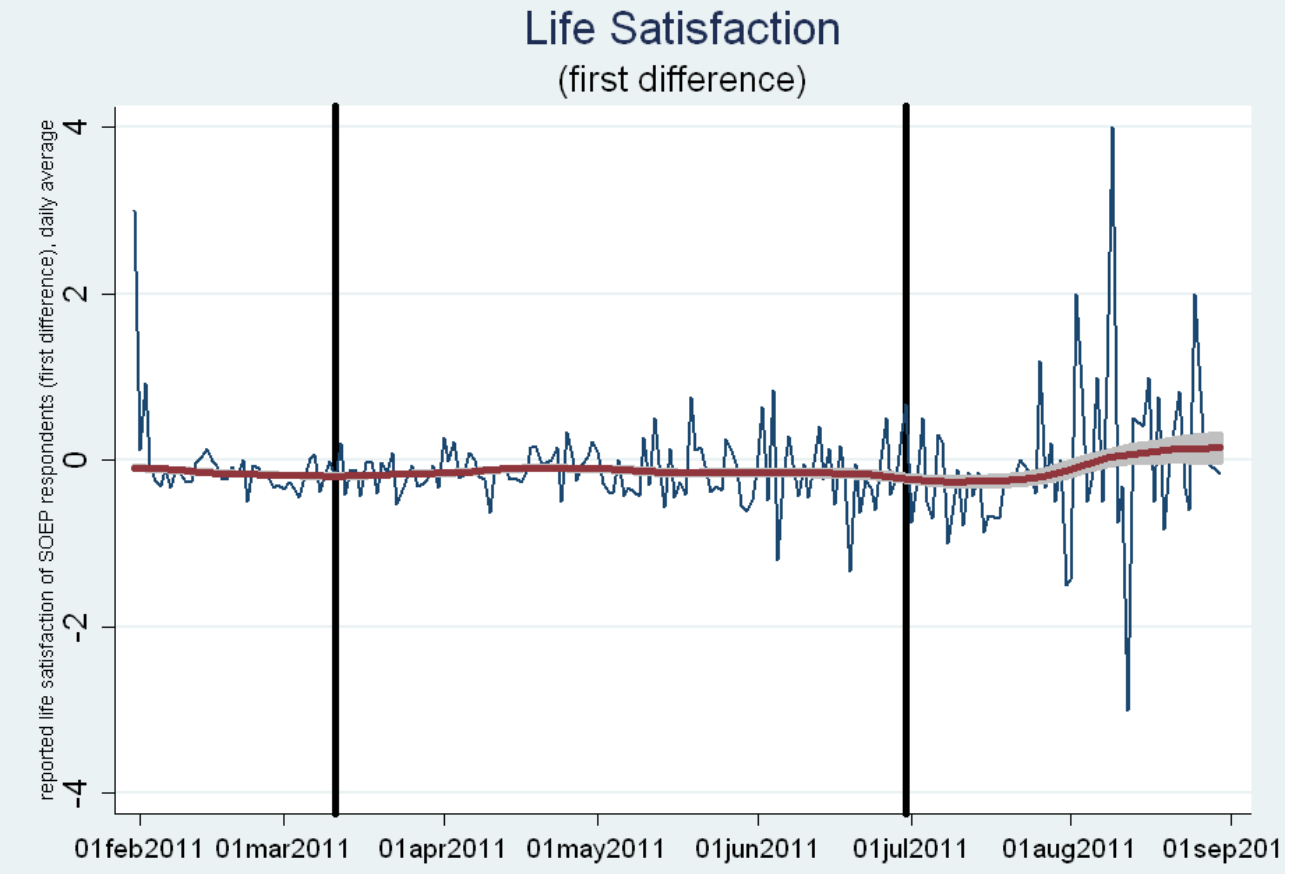

Figure 5: Comparison to the Chernobyl Disaster:

Share of SOEP Respondents Who Are Very Concerned About Environmental Protection

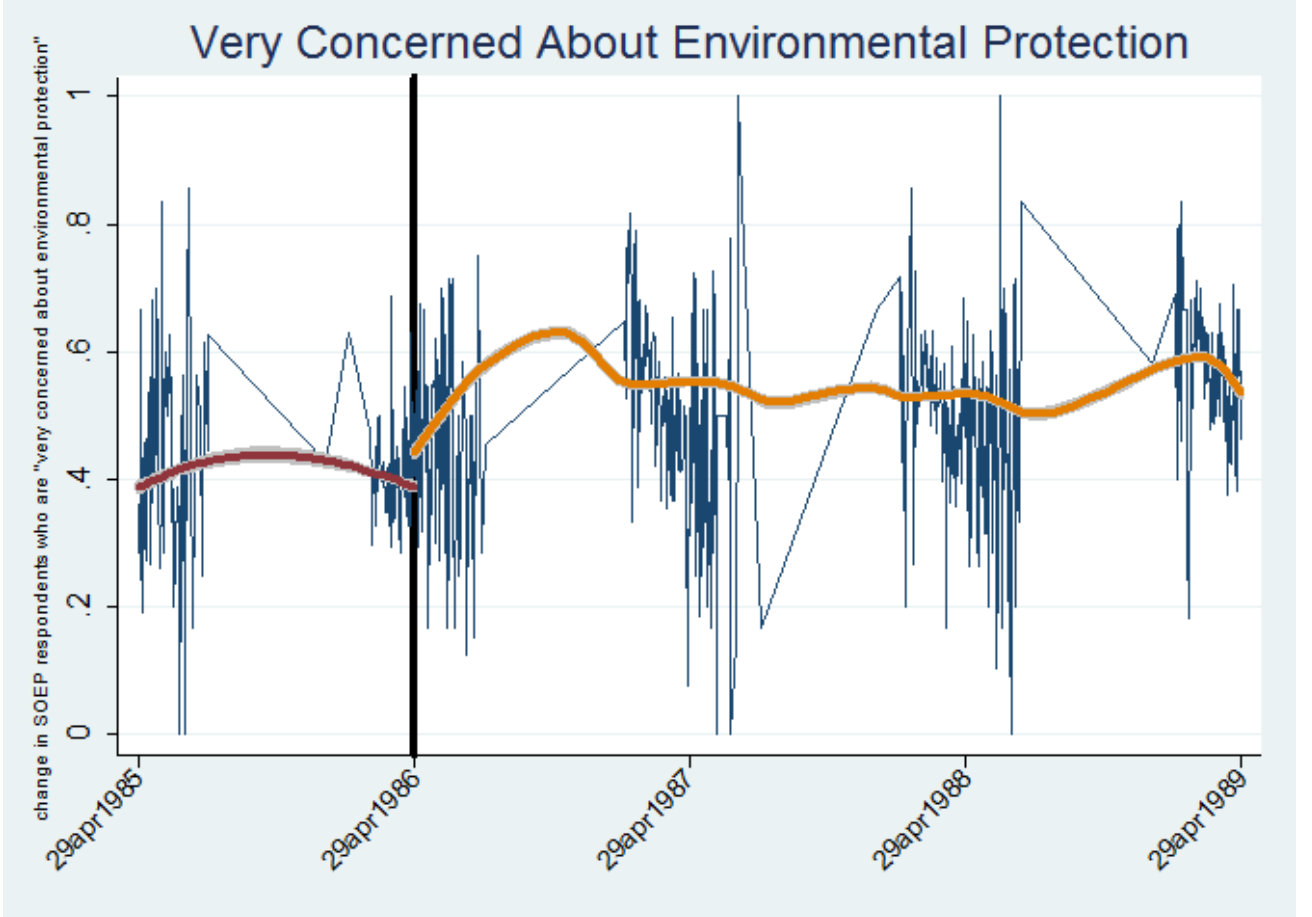


Table 1:

Balancing Properties Between Treatment and Control Group, 2010-2011

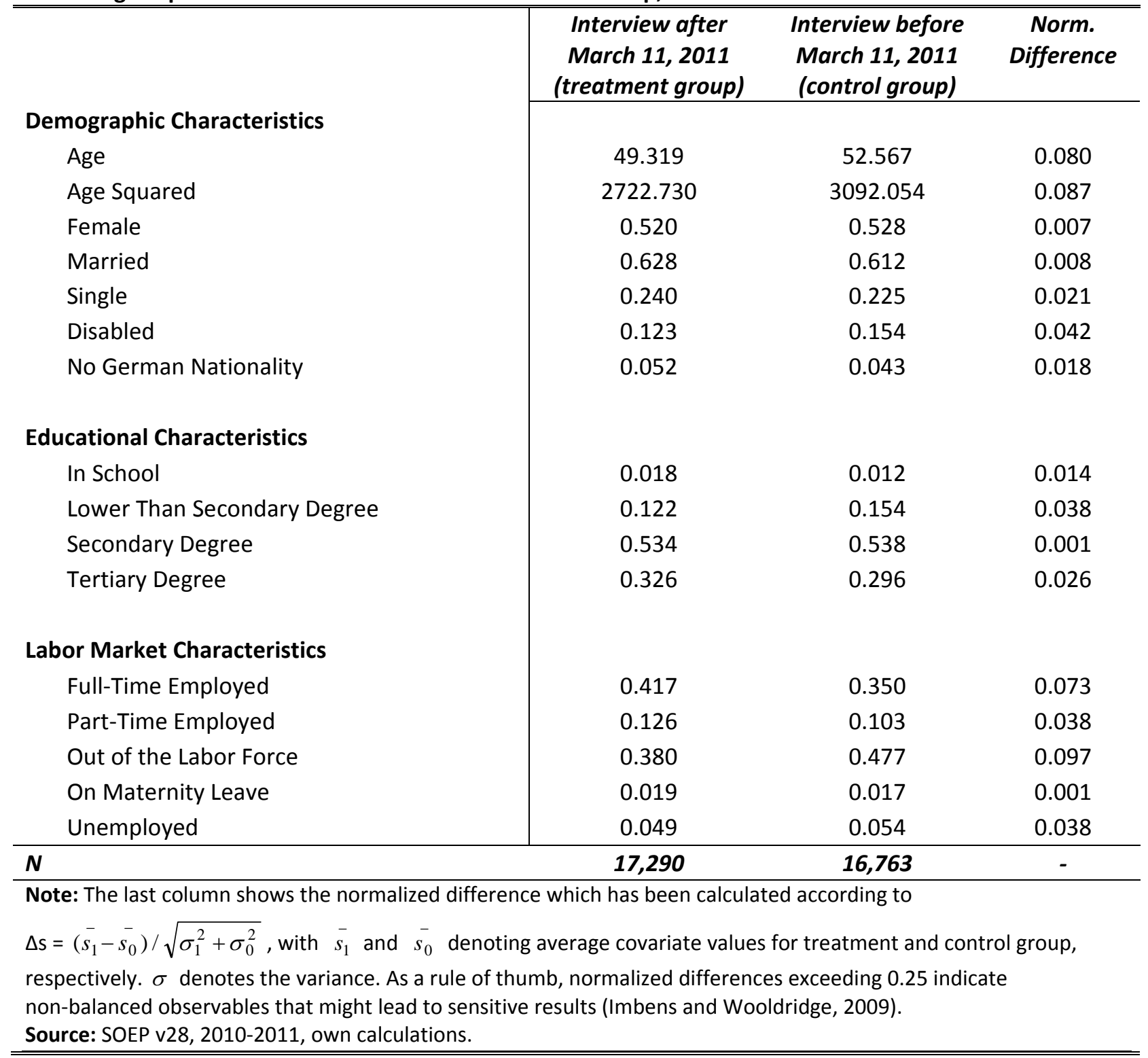




\section{Table 2: Standard}

Effects of the Fukushima Meltdown and the Permanent Shutdown of Nuclear Power Plants in Germany on Environmental Concerns: Short-Term Homogeneous Impacts (2010-2011)

\begin{tabular}{|c|c|c|c|c|}
\hline & \multicolumn{4}{|c|}{ Very Concerned About the Environment } \\
\hline & OLS & OLS & FE & FE \\
\hline PostMarch11 $1_{i, 2011}{ }^{*} 2011$ ("After Meltdown") & $\begin{array}{c}0.050 * * * \\
(0.011)\end{array}$ & $\begin{array}{c}0.051 * * * \\
(0.011)\end{array}$ & $\begin{array}{c}0.062 * * * \\
(0.012)\end{array}$ & $\begin{array}{c}0.062 * * * \\
(0.012)\end{array}$ \\
\hline PostJune $30_{\mathrm{i}, 2011} * 2011$ ("After Permanent Shutdown") & $\begin{array}{c}-0.084 * * * \\
(0.027)\end{array}$ & $\begin{array}{c}-0.087 * * * \\
(0.027)\end{array}$ & $\begin{array}{c}-0.094^{* * *} \\
(0.029)\end{array}$ & $\begin{array}{c}-0.095 * * * \\
(0.030)\end{array}$ \\
\hline PostJune $30_{\mathrm{i}, 2011}$ & $\begin{array}{l}-0.036 \\
(0.025)\end{array}$ & $\begin{array}{l}-0.036 \\
(0.025)\end{array}$ & & \\
\hline \multicolumn{5}{|l|}{ Controls } \\
\hline Demographic Characteristics & No & Yes & No & Yes \\
\hline Month Fixed Effects & Yes & Yes & Yes & Yes \\
\hline$R^{2}$ & 0.003 & 0.012 & 0.005 & 0.006 \\
\hline$N$ & 26,547 & 26,547 & 26,547 & 26,547 \\
\hline \multicolumn{5}{|c|}{$\begin{array}{l}\text { Note: }{ }^{*} p<0.1, * * p<0.05, * * * p<0.01 ; \text { standard errors are in parentheses and clustered at the household level. The treatment statuses are } \\
\text { established based on whether the individuals were interviewed after March } 11 \text { and after June } 30,2011 \text {, respectively. The dependent variable is } \\
\text { a dummy variable which equals one if the individual is very concerned about the environment. } \\
\text { Source: SOEP v28, 2010-2011, unbalanced panel, own calculations. }\end{array}$} \\
\hline
\end{tabular}


Effects of the Fukushima Meltdown and the Permanent Shutdown of Nuclear Power Plants in Germany on Environmental Concerns:

Robustness of Short-Term Homogeneous Impacts (2010-2011)

\begin{tabular}{|c|c|c|c|c|c|c|c|}
\hline & \multicolumn{7}{|c|}{ Very Concerned About the Environment } \\
\hline & $\begin{array}{c}\text { Alternative } \\
\text { date for } \\
\text { Phase Out Bill } \\
\text { (1) }\end{array}$ & $\begin{array}{c}\text { Includes } \\
\text { linear time } \\
\text { trend } \\
(2)\end{array}$ & $\begin{array}{c}\text { Movers } \\
\text { excluded } \\
\text { (3) }\end{array}$ & $\begin{array}{c}\text { Postal } \\
\text { interviews } \\
\text { excluded } \\
\text { (4) }\end{array}$ & $\begin{array}{c}\text { Std. Err. } \\
\text { Clustered at } \\
\text { state level } \\
\text { (5) }\end{array}$ & $\begin{array}{c}\text { Balanced } \\
\text { Sample } \\
(6)\end{array}$ & $\begin{array}{c}\text { Placebo } \\
\text { Treatment } \\
\text { Date (2010) } \\
(7)\end{array}$ \\
\hline PostMarch11 $11_{\mathrm{i}, 2011} * 2011$ & $0.072 * * *$ & $0.062 * * *$ & $0.064 * * *$ & $0.065^{* * *}$ & $0.062 * * *$ & $0.062 * * *$ & $0.013^{* * *}$ \\
\hline ("After Meltdown") & $(0.012)$ & $(0.012)$ & $(0.012)$ & (0.019) & $(0.012)$ & $(0.012)$ & $(0.011)$ \\
\hline PostJune $30_{\mathrm{i}, 2011} * 2011$ & & $-0.095 * * *$ & $-0.109 * * *$ & $-0.139 * * *$ & $-0.095 *$ & $-0.095 * * *$ & $-0.011 * * *$ \\
\hline ("After Permanent Shutdown") & & $(0.030)$ & $(0.031)$ & (0.043) & (0.048) & $(0.030)$ & (0.024) \\
\hline PostMay $30_{\mathrm{i}, 2011} * 2011$ & $-0.100 * * *$ & & & & & & \\
\hline ("After Permanent Shutdown II") & (0.021) & & & & & & \\
\hline \multicolumn{8}{|l|}{ Controls } \\
\hline Demographic Characteristics & Yes & Yes & Yes & Yes & Yes & Yes & Yes \\
\hline Educational Characteristics & Yes & Yes & Yes & Yes & Yes & Yes & Yes \\
\hline Labor Market Characteristics & Yes & Yes & Yes & Yes & Yes & Yes & Yes \\
\hline Year Fixed Effects & Yes & Yes & Yes & Yes & Yes & Yes & Yes \\
\hline Month Fixed Effects & Yes & Yes & Yes & Yes & Yes & Yes & Yes \\
\hline$R^{2}$ & 0.008 & 0.004 & 0.006 & 0.007 & 0.013 & 0.006 & 0.006 \\
\hline $\mathbf{N}$ & 26,547 & 26,547 & 26,150 & 13,446 & 26,547 & 20,317 & 31,221 \\
\hline
\end{tabular}

Note: ${ }^{*} \mathrm{p}<0.1, * * \mathrm{p}<0.05, * * * \mathrm{p}<0.01$; standard errors are in parentheses and clustered at the household level. The treatment statuses are established based on whether the individuals were interviewed after March 11 and after June 30, 2011, respectively. Column (1), as indicated, uses May 30 as the relevant Phase Out Bill date since the policy action was officially announced on that date. The final bill was passed by the German parliament on June 30 , which is the standard Phase Out Bill date in our other specifications. The dependent variable is a dummy variable which equals one if the individual is very concerned about the environment. Column (2) includes a linear time trend. Column (3) excludes movers and shuts down post-Fukushima residential sorting. Column (4) excludes postal interviews and eliminates potential measurement error in the interview date. Column (5) clusters standard errors at the state level. Column (6) balances the sample and column (7) uses March 11, 2010 and June 30, 2010 as treatment dates.

Source: SOEP v28, 2010-2011, unbalanced panel, own calculations. 
Table 4: Effect Heterogeneity

Effects of the Fukushima Meltdown and the Permanent Shutdown of Nuclear Power Plants in Germany on Environmental Concerns:

Short-Term Heterogeneous Impacts (2010-2011)

\begin{tabular}{|c|c|c|c|c|c|}
\hline & \multicolumn{5}{|c|}{ Very Concerned About the Environment } \\
\hline & $\begin{array}{l}\text { Within } 50 \mathrm{~km} \text { to } \\
\text { nuclear power } \\
\text { plant } \\
\text { (1) }\end{array}$ & $\begin{array}{l}\text { Supports } \\
\text { Social Dem./ } \\
\text { Greens } \\
\text { (2) }\end{array}$ & $\begin{array}{l}\text { Risk Averse } \\
\text { (lagged) } \\
\text { (3) }\end{array}$ & $\begin{array}{l}\text { Female } \\
\text { (4) }\end{array}$ & $\begin{array}{l}\text { Above } 40 \\
\text { (5) }\end{array}$ \\
\hline PostMarch11 $1_{i, 2011} * 2011 *$ Within50kmRadius & $\begin{array}{l}-0.010 \\
(0.015)\end{array}$ & & & & \\
\hline PostJune $30_{\mathrm{i}, 2011} * 2011 *$ Within $50 \mathrm{~km}$ Radius & $\begin{array}{c}0.011 \\
(0.042)\end{array}$ & & & & \\
\hline PostMarch11 $1_{i, 2011} * 2011 *$ RedGreen & & $\begin{array}{c}0.013 \\
(0.016)\end{array}$ & & & \\
\hline PostJune $30_{i, 2011} * 2011 *$ RedGreen & & $\begin{array}{c}0.010 \\
(0.047)\end{array}$ & & & \\
\hline PostMarch11 $1_{i, 2011} * 2011 *$ RiskAverse & & & $\begin{array}{c}-0.032^{* *} \\
(0.015)\end{array}$ & & \\
\hline PostJune $30_{i, 2011} * 2011 *$ RiskAverse & & & $\begin{array}{c}0.036 \\
(0.048)\end{array}$ & & \\
\hline PostMarch11 $1_{\mathrm{i}, 2011} * 2011 *$ Female & & & & $\begin{array}{c}0.027^{* *} \\
(0.011)\end{array}$ & \\
\hline PostJune $30_{\mathrm{i}, 2011} * 2011 *$ Female & & & & $\begin{array}{c}-0.081 * * * \\
(0.030)\end{array}$ & \\
\hline PostMarch11 $1_{\mathrm{i}, 2011} * 2011 *$ Above 50 & & & & & $\begin{array}{c}0.001 \\
(0.013)\end{array}$ \\
\hline PostJune $30_{\mathrm{i}, 2011} * 2011 *$ Above 50 & & & & & $\begin{array}{l}-0.034 \\
(0.038)\end{array}$ \\
\hline Within50kmRadius & $\begin{array}{c}0.006 \\
(0.010)\end{array}$ & & & & \\
\hline
\end{tabular}




\begin{tabular}{|c|c|c|c|c|c|}
\hline & $\begin{array}{c}\text { Within } 50 \mathrm{~km} \text { to } \\
\text { nuclear power } \\
\text { plant } \\
\text { (1) }\end{array}$ & $\begin{array}{c}\text { Supports } \\
\text { Social Dem./ } \\
\text { Greens } \\
\text { (2) }\end{array}$ & $\begin{array}{l}\text { Risk Averse } \\
\text { (lagged) } \\
\text { (3) }\end{array}$ & $\begin{array}{c}\text { Female } \\
\text { (4) }\end{array}$ & $\begin{array}{c}\text { Above } 40 \\
\text { (5) }\end{array}$ \\
\hline RedGreen & & $\begin{array}{c}0.116^{* * *} \\
(0.010)\end{array}$ & & & \\
\hline RiskAverse & & & $\begin{array}{l}-0.001 \\
(0.008)\end{array}$ & & \\
\hline Female & & & & $\begin{array}{c}0.047^{* * *} \\
(0.007)\end{array}$ & \\
\hline Above 50 & & & & & $\begin{array}{l}-0.011 \\
(0.013)\end{array}$ \\
\hline PostMarch11 ${ }_{\mathrm{i}, 2011}{ }^{*} 2011$ ("After Meltdown") & $\begin{array}{c}0.049 * * * \\
(0.012)\end{array}$ & $\begin{array}{c}0.067^{* * *} \\
(0.014)\end{array}$ & $\begin{array}{c}0.037^{* * *} \\
(0.012)\end{array}$ & $\begin{array}{c}0.047^{* * *} \\
(0.015)\end{array}$ & $\begin{array}{c}0.053^{* * *} \\
(0.012)\end{array}$ \\
\hline PostJune $30,0_{i, 2011}$ *2011 ("After Permanent Shutdown") & $\begin{array}{c}-0.085^{* * *} \\
(0.030)\end{array}$ & $\begin{array}{c}-0.108^{* * *} \\
(0.037)\end{array}$ & $\begin{array}{l}-0.045 \\
(0.031)\end{array}$ & $\begin{array}{c}-0.075^{*} \\
(0.038)\end{array}$ & $\begin{array}{c}-0.091^{* * *} \\
(0.031)\end{array}$ \\
\hline Demographic Characteristics & Yes & Yes & Yes & Yes & Yes \\
\hline Educational Characteristics & Yes & Yes & Yes & Yes & Yes \\
\hline Labor Market Characteristics & Yes & Yes & Yes & Yes & Yes \\
\hline Year Fixed Effects & Yes & Yes & Yes & Yes & Yes \\
\hline Month Fixed Effects & Yes & Yes & Yes & Yes & Yes \\
\hline$R^{2}$ & 0.023 & 0.013 & 0.012 & 0.012 & 0.012 \\
\hline $\boldsymbol{N}$ & 26,547 & 21,087 & 26,547 & 26,547 & 26,369 \\
\hline
\end{tabular}

Note: $* p<0.1,{ }^{*} p<0.05, * * * p<0.01$; standard errors are in parentheses and clustered at the household level. The treatment statuses are established based on whether the individuals were interviewed after March 11 and after June 30, 2011, respectively. The dependent variable is a dummy variable which equals one if the individual is very concerned about the environment. Each column stands for one OLS regression model similar to the one in equation (1). However, to test effect heterogeneity we always include a triple interaction term, in addition to the variable of interest in levels, to the model as indicated. How the variables in the column headers are generated is explained in Section 3.3. The descriptive statistics are in the Appendix.

Source: SOEP v28, 2010-2011, unbalanced panel, own calculations. 
Table 5: Alternative Well-Being Measures

Effects of the Fukushima Meltdown and the Permanent Shutdown of Nuclear Power Plants in Germany on Alternative Well-Being Measures: Short-Term Homogeneous Impacts (2010-2011)

\begin{tabular}{|c|c|c|c|c|}
\hline & $\begin{array}{l}\text { Life Satisfaction } \\
\text { (1) }\end{array}$ & $\begin{array}{l}\text { Happy } \\
\text { (2) }\end{array}$ & $\begin{array}{l}\text { Sad } \\
(3)\end{array}$ & $\begin{array}{l}\text { Concerned about } \\
\text { climate change } \\
\text { (4) }\end{array}$ \\
\hline PostMarch11 $1_{\mathrm{i}, 2011} * 2011$ & 0.016 & -0.000 & $0.042 * * *$ & $0.049 * * *$ \\
\hline ("After Meltdown") & $(0.024)$ & (0.009) & $(0.012)$ & $(0.011)$ \\
\hline PostJune $30_{\mathrm{i}, 2011} * 2011$ & -0.077 & -0.009 & -0.015 & -0.046 \\
\hline (“After Permanent Shutdown") & $(0.065)$ & $(0.025)$ & $(0.036)$ & $(0.030)$ \\
\hline \multicolumn{5}{|l|}{ Controls } \\
\hline Demographic Characteristics & Yes & Yes & Yes & Yes \\
\hline Educational Characteristics & Yes & Yes & Yes & Yes \\
\hline Labor Market Characteristics & Yes & Yes & Yes & Yes \\
\hline Year Fixed Effects & Yes & Yes & Yes & Yes \\
\hline Month Fixed Effects & Yes & Yes & Yes & Yes \\
\hline$R^{2}$ & 0.018 & 0.009 & 0.007 & 0.005 \\
\hline$N$ & 26,547 & 26,547 & 26,547 & 26,547 \\
\hline \multicolumn{5}{|c|}{$\begin{array}{l}\text { Note: }{ }^{*} p<0.1,{ }^{*} p<0.05, * * * p<0.01 ; \text { standard errors are in parentheses and clustered at the household level. The treatment } \\
\text { statuses are established based on whether the individuals were interviewed after March } 11 \text { and after June } 30,2011 \text {, respectively. } \\
\text { The dependent variables are dummy variables which equal one if the individual is (1) satisfied with life, (2) happy, (3) sad, (4) and } \\
\text { worried about climate change. Each column stands for one FE regression model, except for the first, which is an ordered probit } \\
\text { model. } \\
\text { Source: SOEP v28, 2010-2011, unbalanced panel, own calculations. }\end{array}$} \\
\hline
\end{tabular}


Table 6: Long-Term Impact

Effects of the Fukushima Meltdown and the Permanent Shutdown of Nuclear Power Plants in Germany on Environmental Concerns:

Long-Term Homogeneous Impacts (2009-2012)

\begin{tabular}{|c|c|c|c|c|}
\hline & \multirow[b]{2}{*}{$\begin{array}{c}\text { Unbalanced OLS } \\
2009-2012 \\
\text { (1) }\end{array}$} & \multicolumn{3}{|c|}{ Very Concerned About the Environment } \\
\hline & & $\begin{array}{c}\text { Balanced FE } \\
2009-2012 \\
\text { (2) }\end{array}$ & $\begin{array}{c}2009 \text { vs. } 2012 \\
\text { Unbalanced OLS } \\
\text { (3) }\end{array}$ & $\begin{array}{c}2009 \text { vs. } 2012 \\
\text { Balanced FE } \\
\text { (4) }\end{array}$ \\
\hline $\begin{array}{l}\text { PostMarch11 } 1_{i, 2011}{ }^{*} 2011 \\
\text { ("After Meltdown") }\end{array}$ & $\begin{array}{c}0.064^{* * *} \\
(0.008)\end{array}$ & $\begin{array}{c}0.069^{* * *} \\
(0.010)\end{array}$ & & \\
\hline $\begin{array}{l}\text { PostJune } 30_{\mathrm{i}, 2011} * 2011 \\
\text { ("After Permanent Shutdown") }\end{array}$ & $\begin{array}{c}-0.097^{* * *} \\
(0.019)\end{array}$ & $\begin{array}{c}-0.100^{* * *} \\
(0.026)\end{array}$ & & \\
\hline 2012 & $\begin{array}{l}0.011^{* *} \\
(0.005)\end{array}$ & $\begin{array}{l}-0.007 \\
(0.006)\end{array}$ & $\begin{array}{l}0.010^{* *} \\
(0.005)\end{array}$ & $\begin{array}{l}-0.007 \\
(0.006)\end{array}$ \\
\hline Controls & & & & \\
\hline Demographic Characteristics & Yes & Yes & Yes & Yes \\
\hline Educational Characteristics & Yes & Yes & Yes & Yes \\
\hline Labor Market Characteristics & Yes & Yes & Yes & Yes \\
\hline Year Fixed Effects & Yes & Yes & Yes & Yes \\
\hline Month Fixed Effects & Yes & Yes & Yes & Yes \\
\hline$R^{2}$ & 0.012 & 0.008 & 0.010 & 0.005 \\
\hline$N$ & 58,039 & 31,456 & 58,039 & 31,456 \\
\hline
\end{tabular}

Note: ${ }^{*} p<0.1,{ }^{*} p<0.05, * * * p<0.01$; standard errors are in parentheses and clustered at the household level. The treatment statuses are established based on whether the individuals were interviewed after March 11 and after June 30, 2011, respectively. The dependent variable is a dummy variable which equals one if the individual is very concerned about the environment. Columns (1) and (3) estimate unbalanced OLS, and columns (2) and (4) balanced FE regression models. The first two columns use the years 2009-2012, whereas the last two columns solely compare 2009 with 2012.

Source: SOEP v28, 2009-2012, own calculations. 
Table 7: Long-Term Impact of the Chernobyl Disaster

Effect of the Chernobyl Disaster on Environmental Concerns: Long-Term Homogeneous Impacts (1984-1989)

\begin{tabular}{|c|c|c|c|c|}
\hline & \multicolumn{4}{|c|}{ Very Concerned About the Environment } \\
\hline & $\begin{array}{c}\text { Unbalanced OLS } \\
1984-1987 \\
\text { (1) }\end{array}$ & $\begin{array}{c}\text { Balanced FE } \\
\text { 1984-1987 } \\
\text { (2) } \\
\end{array}$ & $\begin{array}{c}\text { Unbalanced OLS } \\
\text { 1984-1989 } \\
\text { (3) }\end{array}$ & $\begin{array}{c}\text { Balanced FE } \\
1984-1989 \\
\text { (4) }\end{array}$ \\
\hline $\begin{array}{l}\text { PostApril26 } 6_{\mathrm{i}, 1986} * 1986 \\
\text { ("After Meltdown") }\end{array}$ & $\begin{array}{c}0.112^{* * *} \\
(0.017)\end{array}$ & $\begin{array}{c}0.118 * * * \\
(0.017)\end{array}$ & $\begin{array}{c}0.113^{* * *} \\
(0.016)\end{array}$ & $\begin{array}{c}0.116^{* * *} \\
(0.018)\end{array}$ \\
\hline 1987 & $\begin{array}{c}0.151^{* * *} \\
(0.007)\end{array}$ & $\begin{array}{c}0.151^{* * *} \\
(0.010)\end{array}$ & $\begin{array}{c}0.154^{* * *} \\
(0.007)\end{array}$ & $\begin{array}{c}0.160 * * * \\
(0.009)\end{array}$ \\
\hline 1988 & & & $\begin{array}{c}0.137^{* * *} \\
(0.008)\end{array}$ & $\begin{array}{c}0.143 * * * \\
(0.012)\end{array}$ \\
\hline 1989 & & & $\begin{array}{c}0.193 * * * \\
(0.008)\end{array}$ & $\begin{array}{c}0.205^{* * *} \\
(0.015)\end{array}$ \\
\hline \multicolumn{5}{|l|}{ Controls } \\
\hline Demographic Characteristics & Yes & Yes & Yes & Yes \\
\hline Educational Characteristics & Yes & Yes & Yes & Yes \\
\hline Labor Market Characteristics & Yes & Yes & Yes & Yes \\
\hline Year Fixed Effects & Yes & Yes & Yes & Yes \\
\hline Month Fixed Effects & Yes & Yes & Yes & Yes \\
\hline$R^{2}$ & 0.060 & 0.027 & 0.066 & 0.028 \\
\hline$N$ & 43,587 & 33,668 & 62,877 & 42,462 \\
\hline
\end{tabular}

Note: ${ }^{*} p<0.1,{ }^{* *} p<0.05, * * * p<0.01$; standard errors are in parentheses and clustered at the household level. The treatment statuses are established based on whether the individuals were interviewed after April 28, 1986. The dependent variable is a dummy variable which equals one if the individual is very concerned about the environment. Columns (1) and (3) estimate unbalanced OLS, and columns (2) and (4) balanced FE regression models. The first two columns use the years 1984-1987, whereas the last two columns use the years 1984-1989.

Source: SOEP v28, 1984-1989, own calculations. 
Appendix: Descriptive Statistics

\begin{tabular}{|c|c|c|c|c|c|}
\hline & Mean & Std. Dev. & Min. & Max. & Obs. \\
\hline \multicolumn{6}{|l|}{ Dependent Variables } \\
\hline Very Concerned About the Environment & 0.302 & 0.459 & 0 & 1 & 26,547 \\
\hline Very Concerned About Climate Change & 0.294 & 0.455 & 0 & 1 & 26,547 \\
\hline Satisfaction With Life & 7.000 & 1.732 & 0 & 10 & 26,547 \\
\hline Feeling Happy & 0.135 & 0.342 & 0 & 1 & 26,547 \\
\hline Feeling Sad & 0.208 & 0.406 & 0 & 1 & 26,547 \\
\hline \multicolumn{6}{|l|}{ Demographic Characteristics } \\
\hline Age & 51.217 & 17.398 & 18 & 101 & 26,547 \\
\hline Age Squared & 2925.892 & 1809.200 & 324 & 10,201 & 26,547 \\
\hline Female & 0.524 & 0.499 & 0 & 1 & 26,547 \\
\hline Married & 0.629 & 0.483 & 0 & 1 & 26,547 \\
\hline Single & 0.222 & 0.416 & 0 & 1 & 26,547 \\
\hline Disabled & 0.139 & 0.346 & 0 & 1 & 26,547 \\
\hline No German Nationality & 0.046 & 0.210 & 0 & 1 & 26,547 \\
\hline \multicolumn{6}{|l|}{ Educational Characteristics } \\
\hline In School & 0.015 & 0.122 & 0 & 1 & 26,547 \\
\hline Lower Than Secondary Degree & 0.137 & 0.343 & 0 & 1 & 26,547 \\
\hline Secondary Degree & 0.536 & 0.499 & 0 & 1 & 26,547 \\
\hline Tertiary Degree & 0.312 & 0.463 & 0 & 1 & 26,547 \\
\hline \multicolumn{6}{|l|}{ Labor Market Characteristics } \\
\hline Full-Time Employed & 0.391 & 0.488 & 0 & 1 & 26,547 \\
\hline Part-Time Employed & 0.116 & 0.320 & 0 & 1 & 26,547 \\
\hline Out of the Labor Force & 0.423 & 0.494 & 0 & 1 & 26,547 \\
\hline On Maternity Leave & 0.018 & 0.134 & 0 & 1 & 26,547 \\
\hline Unemployed & 0.051 & 0.219 & 0 & 1 & 26,547 \\
\hline \multicolumn{6}{|l|}{ Heterogeneity } \\
\hline Social Democrats/Greens Supporter & 0.214 & 0.410 & 0 & 1 & 26,547 \\
\hline Christian Democrats/Free Market Party Supporter & 0.208 & 0.406 & 0 & 1 & 26,547 \\
\hline Within 50km Radius of Nuclear Power Plant & 0.273 & 0.445 & 0 & 1 & 26,369 \\
\hline Risk Averse (Lagged) & 0.546 & 0.498 & 0 & 1 & 21,087 \\
\hline Above 50 & 0.514 & 0.500 & 0 & 1 & 26,547 \\
\hline
\end{tabular}

